\title{
Stem Cells as a Source of Pancreatic Cells for Production of 3D Bioprinted Bionic Pancreas in the Treatment of Type 1 Diabetes
}

\author{
Michał Wszoła ${ }^{1,2,3}$, Daria Nitarska ${ }^{2}$, Piotr Cywoniuk ${ }^{1}$, Magdalena Gomółka ${ }^{1}$ a and Marta Klak $^{1,2, *(\mathbb{D})}$ \\ 1 Foundation of Research and Science Development, 01-793 Warsaw, Poland; \\ michal.wszola@fundacjabirn.pl (M.W.); piotr.cywoniuk@gmail.com (P.C.); \\ magdalena.gomolka.158@gmail.com (M.G.) \\ 2 Polbionica Ltd., 01-793 Warsaw, Poland; daria.nitarska@polbionica.com \\ 3 Medispace Medical Centre, 01-044 Warsaw, Poland \\ * Correspondence: marta.klak@fundacjabirn.pl
}

check for updates

Citation: Wszoła, M.; Nitarska, D.; Cywoniuk, P.; Gomółka, M.; Klak, M. Stem Cells as a Source of Pancreatic Cells for Production of 3D Bioprinted Bionic Pancreas in the Treatment of Type 1 Diabetes. Cells 2021, 10, 1544. https://doi.org/10.3390/cells10061544

Academic Editor: Claudia Spits

Received: 7 May 2021

Accepted: 15 June 2021

Published: 18 June 2021

Publisher's Note: MDPI stays neutral with regard to jurisdictional claims in published maps and institutional affiliations.

Copyright: (c) 2021 by the authors. Licensee MDPI, Basel, Switzerland. This article is an open access article distributed under the terms and conditions of the Creative Commons Attribution (CC BY) license (https:// creativecommons.org/licenses/by/ $4.0 /)$.

\begin{abstract}
Type 1 diabetes (T1D) is the third most common autoimmune disease which develops due to genetic and environmental risk factors. Often, intensive insulin therapy is insufficient, and patients require a pancreas or pancreatic islets transplant. However, both solutions are associated with many possible complications, including graft rejection. The best approach seems to be a donorindependent T1D treatment strategy based on human stem cells cultured in vitro and differentiated into insulin and glucagon-producing cells ( $\beta$ and $\alpha$ cells, respectively). Both types of cells can then be incorporated into the bio-ink used for 3D printing of the bionic pancreas, which can be transplanted into T1D patients to restore glucose homeostasis. The aim of this review is to summarize current knowledge about stem cells sources and their transformation into key pancreatic cells. Last, but not least, we comment on possible solutions of post-transplant immune response triggered stem cell-derived pancreatic cells and their potential control mechanisms.
\end{abstract}

Keywords: stem cells; pancreas; 3D bioprinting; diabetes; CRISPR/Cas9; alpha cells; beta cells

\section{Introduction}

The first successful isolated and cultured mouse (1981) [1,2] and human (1998) [3] embryonic stem cells (mESC, hESC, respectively) were milestones in the field of cell culturing, tissue engineering, disease modeling, and other fields of life sciences [4]. Stem cells were characterized with a potential to transform into any particular cell type of all three germ layers (ectoderm, endoderm, or mesoderm) and high proliferation rate which makes them, theoretically, an unlimited source of cells of any type [5-7]. When properly stimulated, stem cells have the ability to create particular tissue, including tumors and tissues disrupted by a genetic abnormality (i.e., when derived from patients suffering from a particular disorder [6,8]), or even clone the whole organism [9]. Such a groundbreaking discovery has elevated biological sciences to a significantly advanced level by creating opportunities to control the cell fate and culture cellular structures of higher level. On the other hand, such knowledge has raised serious ethical concerns about the embryonic source of stem cells and the ability to manipulate new life. Since then, numerous works have been published which describe new stem cell sources, precise protocols to create them and influence their fate, and present stem cell-based results of high value [10-15]. Application of stem cells is also thought to be a reasonable and promising pathway in seeking efficient therapy for Type 1 diabetes (T1D) [16-19], an immune-auto-aggressive disorder resulting in the destruction of pancreatic insulin-producing $\beta$-cells followed by glucose imbalance and its systemic repercussions [20]. The aim of this review is to summarize current knowledge about stem cell sources and their transformation into key pancreatic cells. Last, but not least, we comment on possible solutions of post-transplant immune response triggered stem cell-derived pancreatic cells and their potential control mechanisms. 


\section{Structure of the Pancreas and the Role of Individual Cells}

The pancreas is an essential organ for the proper metabolism of nutrients and has both an endocrine and an exocrine function [21]. The exocrine part of the pancreas is made up of cells that secrete digestive enzymes and make up about $98 \%$ of the adult organ. Within the parenchyma are the islets of Langerhans that contain endocrine cells that produce hormones that play a key role in the maintenance of glucose homeostasis in the body. Each islet is a micro-organ that contains at least 4 cell types, including $\beta$ (insulin), $\alpha$ (glucagon), $\delta$ (somatostatin), $\varepsilon$ (ghrelin), and PP (pancreatic polypeptide) cells [22]. Type 1 diabetes (T1D) is one of the many serious diseases caused by disturbances in the functioning of the pancreas. It is one of the most common chronic diseases of the developmental age [20]. This heterogeneous disorder is characterized by the destruction of $\beta$ cells, resulting in a complete insulin deficiency. In this type of diabetes there are 2 additional types: (a) autoimmune $\beta$-cell destruction, and (b) diabetes mellitus being idiopathic $\beta$ cell destruction or failure [23,24]. T1D accounts for $5 \%$ to $10 \%$ of all diabetes cases worldwide. It is a chronic disease that causes many deaths every year. The susceptibility and resistance to T1D are caused by, among other things, the human HLA antigen complex, which is located on chromosome 6-primarily HLA class II [25]. Apart from genetic factors, age and sex, the so-called environmental risk factors are more and more often mentioned, acting early in life on genetically susceptible people, may trigger adverse immune processes $[24,26]$.

\section{Available Treatments for Patients with Type 1 Diabetes}

For patients with Type 1 diabetes, life-saving treatment is multiple blood glucose control and administration of fast or slow-acting insulin. Glycemic control is currently the basic and best (though burdensome) treatment for patients, and it often affects their quality of life [24]. In the mid-1990s, insulin pumps became commonplace. They are small devices that enable continuous, subcutaneous infusion of insulin. The introduction of this type of device has eliminated the need for frequent punctures [27]. Equally important in the treatment of Type 1 diabetes is adequate physical activity and proper nutrition. It has been shown that a healthy lifestyle and frequent glycemic control significantly postpone the occurrence of life-threatening diabetic complications. However, despite increasing awareness, these complications are still the leading cause of death. Major complications include hyperglycemia, nephropathy, retinopathy, cardiovascular disease (CVD), and neuropathy [27-30]. In patients with diabetic autonomic neuropathy, life-threatening hypoglycemia can occur as a result of an impaired ability to recognize hypoglycemia. In fact, $6 \%$ of all deaths in patients with diabetes are due to severe hypoglycemia [31], especially at night. The only successful treatment for patients with the secondary complications of T1D is the transplantation of a whole pancreas or isolated pancreatic islets. Although pancreas transplantation can produce good long-term results in some patients, this treatment carries a risk of serious postoperative complications, such as acute rejection of graft, infections, or bacteremia [32-34]. Pancreas transplantation may be more appropriate for younger patients with fewer CVD complications. Those with a higher rate of CVD should rather be qualified for clinical islets transplantation (CITx) but this procedure is at a crossroads. Since the introduction of the Edmonton protocol [35], according to which islets often derived from two or three fresh islets preparations (around 13,000 islets equivalents (IE) $/ \mathrm{kg}$ recipient body weight) are infused into the patient's portal vein and special immunosuppression in which avoidance of corticosteroids and application of potent immunosuppression is very relevant, the improvement in islets survival was noticed. Nevertheless, improving longterm results is hard to achieve, even for the researchers who developed the protocol [36]. It is mainly due to islets apoptosis because of lack of extracellular matrix and lack of specific vasculature which is destroyed during the process of islets isolation. Another difficulty is an instant blood-mediated reaction observed after transplantation into a portal vein which diminishes the number of living islets. Developing new implementation sites, such as gastric submucosa [37-39], led to some improvement but could not solve a problem. 
There is a need to develop a technique as efficient as pancreas transplantation but with a complication rate close to the CITx procedure, thus to produce an organ with extracellular matrix and vasculature around islets, but one which is not complicated like in the native pancreas. Another important goal is to find a source of islets ( $\alpha$-and $\beta$-cells at least) for transplantation excluding the use of donors' organs, preferably with patients' own cells. It could also help in reducing or even omitting the need for an immunosuppressive treatment intake. Much interest is involved in stem cell transformation as a potential source of $\alpha$ and $\beta$-cells for the treatment of diabetes. Moreover, observing the current progress in the development of medicine and sciences in the field of biotechnology, tissue engineering, and cellular transformation, the transformation of stem cells taken from the patient and their differentiation into insulin and glucagon producing cells seems a reasonable and very promising approach. Additionally, stem cells with ablation of HLA complex gain more and more interest as they give the possibility to construct universal cell lines which, can be applied for any patient without the need for immunosuppression [40].

\section{Embryonic Stem Cells (ESC)}

Stem cells derived from the inner cell mass of blastocyst isolated and cultured for the first time from a mouse in the early $80^{\prime}$ [1,2] through non-human primates [41] to successful isolation of hESC line in 1998 [3]. They characterize by high self-renewal potency and grow in tightly packed colonies in culture [42]. ESCs can be distinguished by the specific expression profiles of transcription factors (inhibiting activity of repertoire of the genes driving differentiation pathways) including SSEA-3, SSEA-4, TRA-1-60, TRA1-81, Oct 3/4, and Nanog with simultaneous lack of SSEA-1 [42]. ESCs have paved the way in developmental biology, tissue engineering, cellular, and animal-human disease modeling, and regenerative medicine. However, while ESCs derived from animal models are widely used in basic research without major concerns, hESCs' application raises ethical issues due to the human origin [43-45]. Much has been done since 1998 to improve the techniques of obtaining hESCs and their implementation in clinical procedures. First of all, a blastocyst derivation protocol has been upgraded which allows obtaining a single ESC from 8-cell blastomere, an earlier developmental stage of the blastocyst, without damaging the blastomere [46]. As ESCs require specific growing conditions including co-culturing with feeder cells, originally mouse embryonic fibroblasts (MEF) have been used. That, in turn, limited translation of isolated hESCs to clinical procedures because of the risk of xenotic antigens transmission. Currently, MEFs have been replaced with human feeder cell lines and feeder-free chemically supplemented culturing media [47-50]. Yet, the fact that hESCs are obtained during in vitro fertilization (IVF) procedure which does not meet the acceptance of part of the society is impossible to bypass. Another obstacle is the embryonic origin of hESCs. As in the vast majority of cases, hESCs cannot be acquired from the patient (it could be possible only for patients born by IVF) they can be transplanted only as an allograft which implicates the host's immune system suppression.

\section{Adult Stem Cells}

Populations of cells retaining pluri- or multipotency found in adult tissues or organs such as bone marrow [51], olfactory mucosa [52], or mammary gland [53]. They reside in specific niches with microenvironment allowing them to keep undifferentiated state and replace damaged or dying specialized cells of the particular tissue [54]. One of the most ubiquitous and exploited adult stem cells are mesenchymal stem cells (MSC), spindleshaped cells taken initially as fibroblasts [55] with specific surface protein markers set expressed $\left(\mathrm{CD}_{3}{ }^{+}, 90^{+}, 105^{+}, \mathrm{CD} 14^{-}, 34^{-}, 45^{-}\right)[56]$ occurring, among others, in adipose tissue [57], Wharton's jelly, umbilical cord, or dental pulp. As mentioned, tissues treated as medical waste during procedures (liposuction, birth delivery, and dental extraction, respectively), they are attractive sources of easily accessible MSCs, and the ways of acquisition cause no ethical conflicts. What is more, it is possible to obtain MSCs directly from the patient, hence, re-transplanted cells will exhibit full histocompatibility. MSCs are capable 
of differentiating into chondrocytes, osteoblasts, neurons, myocytes, and cardiomyocytes, hepatocytes, and adipocytes, therefore, their application is limited [58]. Nonetheless, this differentiation spectrum is broad enough to place the MSCs in the spotlight of regenerative medicine. Recent works suggest MSCs' role in tissue regeneration by immune system modulation and stimulation of angiogenesis [59-64]. Several others showed their utility after ex vivo propagation and nascent differentiation, as well as in situ and systemic injection in vivo. Simultaneously, works on broader use, including MSC-derived $\beta$-cells, are ongoing $[65,66]$.

Currently, three approaches how MSCs could be applied to treat T1D are tested. The first approach is the use of MSC-derived cells which will be able to produce insulin and restore normoglycemia. There are a few reports which show that insulin-producing cells could be derived from MSCs [65-71]. Nevertheless, it is likely that the results presented in those studies are biased by the fact that only insulin concentration was evaluated while C-peptide was not determined. Only in the study performed by Prabakar et al. 2012, the level of the C-peptide was elevated after glucose stimulation in vitro [65]. The most challenging problem is related to the functionality of obtained cells. Thus, they are capable of insulin secretion, show expression of pancreatic transcription factors like PDX1, NEUROD1, NKX6.1 but they are not fully mature $\beta$-cells, so their ability to restore normoglycemia is limited. The second idea is to use undifferentiated MSCs to generate $\beta$-cells through direct trans-differentiation in vivo after transplantation, but this approach has scarcely been studied [72-74]. Despite that, two clinical trials where MSC-derived pancreatic progenitors generated in vitro maturated into $\beta$-cells after transplantation took place $[75,76]$. The outcome was quite promising. An increase in the amount of the C-peptide in serum and improved $\mathrm{HbA1}$ c values were obtained. The third approach how to use MSCs in T1D treatment which is currently the most often evaluated is to use undifferentiated MSCs to support islets health and survival [77-82]. There are a few potential mechanisms by which MSCs could work like reduction in inflammation, secretion of growth factors, and protection against hypoxia [83-85].

There is a premise that adult stem cells could be obtained from the pancreas. It was noticed that pancreatic exocrine cells like duct epithelial cells and acinar cells have differentiation potential and could be regarded as pancreatic progenitor cells (PPC). Transdifferentiation of ductal or acinar cells could be a potential source of $\beta$-cells for T1D treatment. Trans-differentiation of the $\alpha$-cells into insulin-producing $\beta$-cells was described in mice where $\beta$-cells were ablated [86,87]. It was also showed that insulin-producing cells can be generated from the adult duct cells by glucagon-like peptide-1 (GLP-1) treatment [88]. The presence of PPCs was confirmed in the rats and humans duct, and the differentiation potential of those cells was evaluated [89,90]. Additionally, acinar cells have been proved to be able to transdifferentiate into $\beta$-cells in vivo and in vitro with a generation of the duct cells as in-between step [91-95].

\section{Induced Pluripotent Stem Cells (iPSC)}

In 2006, Kazutoshi Takahashi and Shinya Yamanaka have published crucial results presenting a defined group of four transcription factors (TF), Oct3/4, Sox2, Klf4, and c-Myc (OSKM, Yamanaka factors), which overexpressed in embryonic and adult fibroblasts restored their pluripotency [96]. Since then, the protocol to obtain reprogrammed cells with stem cell-like morphology, potency, and expression profile called induced pluripotent stem cells (iPSC) have been widely implemented and developed [50,97-100]. Since they can be obtained from any cell type iPSCs have become of great interest as theoretically unlimited sources of stem cells. Human iPSCs (hiPSC) derived from easily accessible cell sources such as skin graft [101], peripheral blood [102], or urine [103] can be considered as an advantageous alternative of stem cells applied in regenerative medicine due to minimally invasive collection from the patient and autografted without immunomodulation (Figure 1). Moreover, hiPSC-based therapy does not raise ethical questions concerning the source of stem cells. Since 2006, the protocol of iPSC derivation has been extensively im- 
proved. One of the basic concerns was potential tumorigenicity caused by the uncontrolled activity of Klf4 and c-Myc which are defined as proto-oncogenes [97,104]. Across years the number and composition of TF cocktails have been modified including the addition of other proteins such as Nanog, Lin28, and Esrrb [105-107] and reduction to only two or even one component [108-111]. Although these manipulations aimed to affect expression as little as possible, another problem to tackle was the efficient delivery of exogenic factors and their repercussions. Initially, transformed cells were transduced with lenti- and retroviruses carrying open reading frames for particular factors [97,101]. Such approach raised the risk of spontaneous integration of viral DNA to the cellular genome which, in turn, could lead to increased oncogenic activity, especially in the region of the c-Myc gene [104,112]. To circumvent this, novel transformation strategies have been developed based on nonintegrating viruses, small molecules, or synthetic mRNA. The first wave of improved solutions has offered a variety of viral-origin non-integrating DNA delivery approaches including PiggyBac transposon/transposase system with self-excision activity [113,114], non-integrating Sendai virus carriers [115,116], and Epstein-Barr virus-derived episomal DNA plasmid replication $[117,118]$. Another approach emerged from techniques of in vitro transcription and assumes introduction to the cell mRNA of protein of interest $[119,120]$. Although the techniques of non-integrating DNA delivery characterize with high efficiency they have been shown to increase the risk of chromosomal aberrations during cell division. On the other hand, the mRNA delivery approach providing no interaction with the host's genome, therefore, less invasive revealed efficiency below $30 \%$ and is time-consuming [13]. Another promising and extensively developed approach of pluripotency induction is the affection of signal transduction pathways with small molecules. Signaling pathways such as Wnt/ $\beta$-catenin or MAPK/ERK responsible for cell division, cell cycle control, inhibition of apoptosis [121-126], etc., have been shown to affect the cellular state of pluripotency after particular small molecule cocktail treatment including, among others, vitamin $\mathrm{C}$, valproic acid, GSK-3 inhibitor, or 5-aza-2-deoxycytidine [127-131]. Protocols for small molecules-based iPSCs are constantly upgraded and modified as dozens of molecules have the potential to modulate essential signaling pathways. As an example, in the work of Zhao and colleagues, the authors presented a 1000-fold more efficient iPSC protocol by adding four compounds to a seven-component small molecule cocktail established two years earlier [131,132]. Although delivery of small compounds is much more efficient, broad knowledge about the role of particular signaling pathways in cellular processes and potential off-targeting of tested compounds is pivotal.

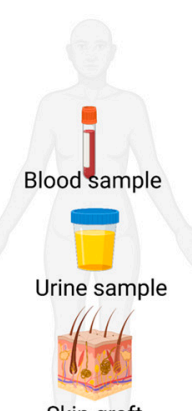

Skin graft
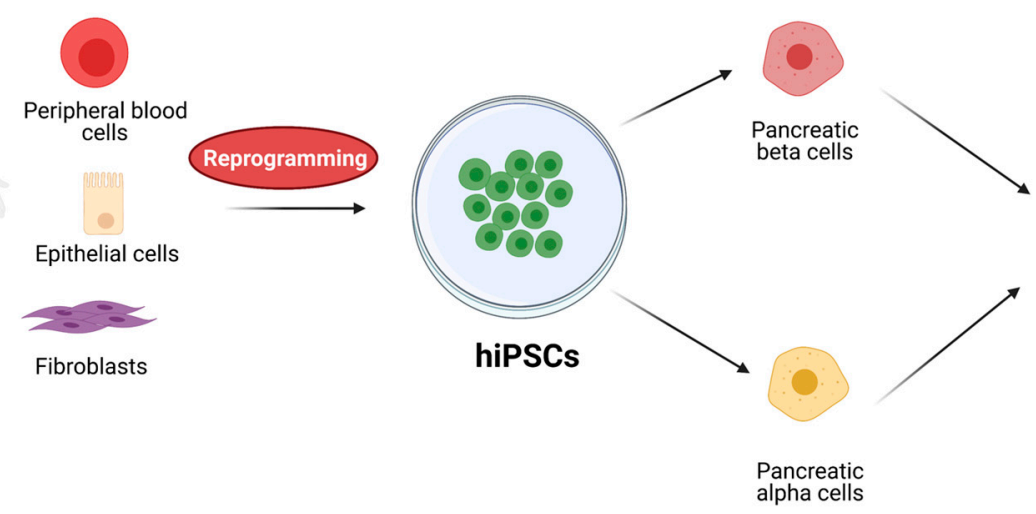

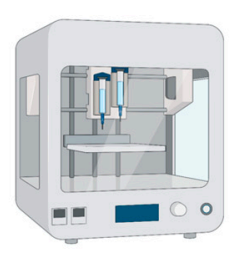

3D bioprinted bionic pancreas

Pancreatic
alpha cells

Figure 1. Schematic representation of iPSCs sources, possible differentiation, and application for 3D bioprinting of bionic pancreas. Created with BioRender.com accessed on 17 June 2021.

\section{Available $\beta$-Cell Differentiation Protocols}

Currently, scientists are highly focused on establishing the perfect differentiation protocol that will allow the transformation of hiPSCs or hESCs into functional insulinproducing cells. Thanks to this interest, several protocols have been established until now. 
In Table 1, there is a summary of the most commonly used protocols [15]. According to available literature, the differentiation of hPSCs into $\beta$-like cells could be achieved by the application of listed below growth factors and small molecules [133-139] (Figure 2). First, by using various growth factors (activin A, BMP4, Wortmanin, CHIR99021, FGF2, FGF7, KGF, bFGF, Vit C, IDE1, IDE2, GSK3 $\beta$ inh, TGF- $\beta$ inh, Wortmannin) hESCs or hiPSCs are differentiated into definitive endoderm cells. This step can be confirmed by analysis of major markers-FOXA2, SOX17, and CXCR4. The next step is transformation into multipotent pancreatic progenitors (growth factors: RA, EGF, KGF, FGF7, FGF10, Noggin, Indolactam V, Nicotinamide, Cyclopamine, SANT1, Vit C, BMP inh, SHH inh). This step is confirmed by markers PDX1, NKX6.1, and SOX9. The second to last step is transformation into endocrine progenitors with the use of growth factors (RA, EGF, T3, FGF7, SANT1, Noggin, Betacellulin, Heparin, Vit C, Alk5 inh, BMP inh, SHH inh, $\gamma$-secretase inh). It can be deemed successful if markers PDX1, NKX6.1, NEUROG3, and NEUROD1 are distinguishable. The last step is creating maturing $\beta$-like cells with the use of T3, Vit E, Betacellulin, Heparin, Vit C, N-cys, Alk5 inh, and Axl inh. $\beta$-like cells are achieved if markers such as PDX1, NKX6.1, NEUROD1, MAFA, PAX6, MNX1, and Insulin are present.

Table 1. List of available protocols for stem cell differentiation into $\beta$-cells.

\begin{tabular}{|c|c|c|}
\hline Authors & $\begin{array}{l}\text { Growth Factors and Small Molecules Used in the } \\
\text { Study }\end{array}$ & Outcome \\
\hline $\begin{array}{l}\text { Zhang et al., } 2009 \\
\text { [140] }\end{array}$ & $\begin{array}{c}\text { Act A, Wort, RA, Noggin, FGF7, EGF, Nico, bFGF, } \\
\text { Ex-4, BMP4 }\end{array}$ & $\begin{array}{l}\text { Successful differentiation into mature } \\
\text { insulin-positive cells }\end{array}$ \\
\hline $\begin{array}{l}\text { Rezania et al., } 2014 \\
{[141]}\end{array}$ & $\begin{array}{l}\text { GDF8, GSK3 } \beta \text { inh, FGF7, Vit C, RA, SANT, TPB, LDN, } \\
\text { SANT, Alk5 inh, T3, LDN, GS inh XX, N-cys, AXL inh }\end{array}$ & $\begin{array}{l}\text { Approximately } 50 \% \text { of cells were } \\
\text { insulin-positive }\end{array}$ \\
\hline $\begin{array}{l}\text { Pagliuca et al., } 2014 \\
\text { [133] }\end{array}$ & $\begin{array}{c}\text { Act A CHIR, KGF, RA, SANT1 LDN, PdbU, T3, XXI, } \\
\text { Alk5 inh, Heparin, Betacelluin, CMRL }\end{array}$ & Around $33 \%$ of cells were C-peptide-positive \\
\hline $\begin{array}{l}\text { Russ et al., } 2015 \\
\text { [134] }\end{array}$ & $\begin{array}{c}\text { WNT3a, Act A, TGFb inh, KGF, RA, Cyclopamine, } \\
\text { Noggin, EGF, TBP, Alk5 inh }\end{array}$ & $\begin{array}{l}\text { Simplified protocol, around } 23 \% \\
\text { C-peptide-positive cells }\end{array}$ \\
\hline $\begin{array}{l}\text { Nair et al., } 2019 \\
\text { [142] }\end{array}$ & $\begin{array}{c}\text { Wnt3a, Act A, TGB inh, KGF, RA, EGF, ALK5 inh, XX } \\
\text { inh, LDN, Vit C }\end{array}$ & $\begin{array}{l}\text { Clustering of immature } \beta \text {-like cells as a } \\
\text { critical step in gaining full functionality }\end{array}$ \\
\hline $\begin{array}{l}\text { Li et al., } 2020 \\
\quad[143]\end{array}$ & $\begin{array}{c}\text { Act A, Chir99021, FgF- } \beta \text {, Vit C, KGF, Sant1, RA, Noggin, } \\
\text { EGF, RepSox, GC1, LDN, CoE, Y-27632, R428, } \\
\text { Trolox, N-cys }\end{array}$ & $\begin{array}{l}\text { Generation of pancreatic like islets that } \\
\text { contained approximately } 30-40 \% \text { of } \\
\beta \text {-like cells }\end{array}$ \\
\hline $\begin{array}{l}\text { Yoshihara et al., } 2020 \\
\text { [144] }\end{array}$ & $\begin{array}{c}\text { Act A, GSK3 } \beta \text { inh, FGF7, Vit C, RA, TGF } \beta \text { inh, BMPR } \\
\text { inh, Hedgehog inh, PKC, T3, Alk5 inh, Notch inh, Vit C, } \\
\text { Vit E, cAMP, WNT4 }\end{array}$ & $\begin{array}{l}50-60 \% \text { of human islets-like organoids cells } \\
\text { expressed insulin and } \beta \text {-cells markers }\end{array}$ \\
\hline
\end{tabular}

The first systematized method allowing for differentiation into insulin-producing cells was introduced by Zhang et al. in 2009 [140]. It involved both, hESCs, and hiPSCs and the authors managed to establish cultures of mature pancreatic insulin-producing cells. The protocol consisted of 4 major steps, as the review by Cierpka-Kmiec et al. suggests, which go in order: (1) Endoderm induction (Activin A, Wortmannin); (2) Pancreatic specialization (Retinoic acid, FGF7, NOGGIN); (3) Progenitor expansion (EGF); and (4) Maturation (bFGF, Exendin-4, BMP4). Every step was confirmed by proper expression markers, in order: (1) Sox17, Foxa2; (2) Pdx1, Pax1, Pax6, Hnf6; (3) Pdx1, Foxa2, Sox9, Hnf1B; (4) MafA, insulin, Glut2, Nkx6-1, Glucokinase Tcf1. In 2014, Rezania et al. [141] created a more concise and detailed method, which was based on previously reported one and it involved hESCs. The main difference was the number of steps taken during differentiation, as it amounted to 7 main stages: definitive endoderm, primitive gut tube, posterior foregut, pancreatic endoderm, pancreatic endocrine precursors, immature $\beta$-cells, and maturing $\beta$-cells. In this protocol, researchers did not use Activin A in any of the steps, instead, they relied on GDF8, and CHIR-99021 during the transformation into definitive endoderm. In later steps, they implemented (among others) Ascorbic acid (Vit C), FGF7, SANT-1, Retinoic 
acid, LDN193189, and at the end T3, ALK5 inhibitor II and XXiI. The same approach was used by Petersen et al. in 2017 [145]. Additionally, in 2014, another group of scientists designed a protocol for the transformation of hPSCs into stem cell-derived $\beta$-cells [133]. Their goal was to create a strategy for the large-scale production of functional human $\beta$-cells from hPSCs in vitro. They managed to achieve this by comparing and designing a 6-step protocol which is a modification of a standard protocol and it takes place in a three-dimensional cell culture system. Growth factors used involved Activin A, CHIR99021, KGF, SANT-1, Retinoic Acid, LDN193189, XXI, ALK5 inhibitor II, and T3. Its stages and growth factors prove it to be a mash-up of protocols described above. Other protocols that describe the transformation of stem cells into insulin-producing cells are variations of the ones mentioned in detail in earlier sections of this review. They usually differ slightly in the concentration of added growth factors or describe a different number of stages (though with highly similar growth factor additions and medium exchanges [134,146-148]. Interesting advancement was implemented by Nair et al. 2019 [142]. Although using a quite sophisticated process, divided indirectly into 10 steps, they performed isolation, sorting, and reaggregation of cells on day 20 of culturing and transformation to allow clustering of immature $\beta$-like cells. This allowed them to create islet-sized enriched $\beta$ clusters (eBC). Li et al. 2020 modified the existing protocols for application in the $\mathrm{H} 9$ hESC line and proposed $\beta$-like cells population enrichment by sorting only $\mathrm{CD}^{-}{ }^{-}$cells, which are characterized by higher insulin production and spontaneous formation of islets like organoids [143]. Another interesting approach was applied by Yoshihara et al. 2020. They identified that non-canonical WTN4 signaling is important for the maturation of $\beta$-like cells, which after generation of human islet-like organoids, and transplantation into diabetic mice were able to restore the glucose homeostasis [144].
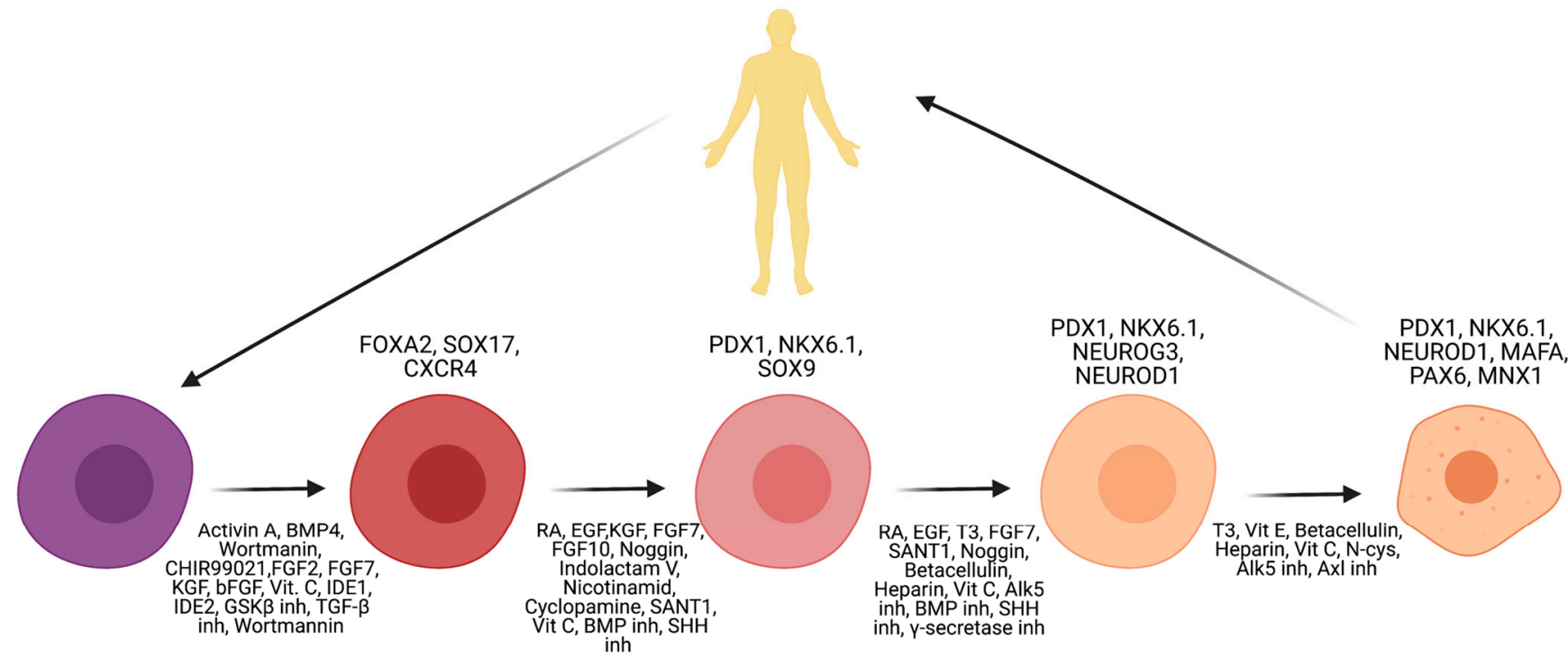

Human Pluripotent Stem Cells
Endoderm Cells

Endocrine Progenitors
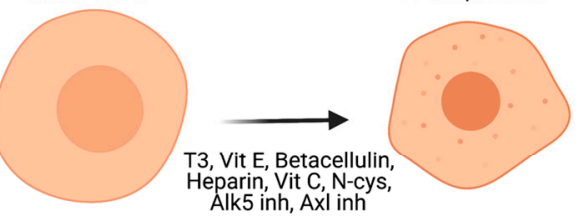

$\beta$-like cells

Figure 2. Schematic representation of stem cells differentiation protocol into $\beta$-like cells. Created with BioRender.com accessed on 17 June 2021.

\section{Challenges in Obtaining Fully Maturated $\beta$-Cells}

All described above protocols lead to obtaining $\beta$-like cells which are able to secrete insulin and C-peptide in vitro. Nevertheless, very often they display immature $\beta$-cells characteristics, such as co-expression of insulin/C-peptide and glucagon or somatostatin [149-151] and low levels of insulin/C-peptide secretion [152,153]. Usually, just a small fraction of $\beta$-like cells show calcium response to glucose, which is usually 
slower and lower compared to adult islets [133,134,141]. Frequently, they are also not able to terminate calcium flux when glucose is not present, and they are not able to quickly secrete insulin in dynamic perfusion assay [141]. Another drawback is that transplanted $\beta$-like cells, in vivo can secrete insulin only after $2-6$ weeks post-transplantation whereas the human islets are able to do it immediately $[133,134,141]$. Another approach taken by scientists is in vivo maturation of the pancreatic endoderm or pancreatic progenitors to mature $\beta$-cells. It was shown that cells transplanted into immunodeficient mice or rats were able to differentiate and maturate into pancreas $\beta$-cells which were able to secrete C-peptide in response to meal or glucose challenge [154-156]. The big drawback of this approach is the long time that is needed to reach maturation by transplanted cells. So far this approach was only explored in mice and rats, and even for those two closely related species differences in the fate choice between pancreatic endocrine and exocrine cells and $\alpha$ and $\beta$ cell lineages were significant [156]. Considering that the maturation environment may differ even among human recipients probably is better to focus more on the in vitro differentiation to be sure what kind of the cell population is transplanted into a patient and to be able to reach normoglycemia immediately after transplant as it takes place during human islets transplantation. Despite those drawbacks, company ViaCyte performed two clinical studies where hESC pancreatic progenitors [154,157] were transplanted into T1D patients (NCT02239354, NCT03162926). The main difference between the two trials was applying different encapsulation devices and using modified membranes, which seems to be crucial for successful treatment. Results obtained during second clinical studies showed that transplanted cells secrete C-peptide and positive results were reported for $30 \%$ of the patients [158]. In the future, companies plan to further optimize encapsulation strategies.

$\beta$-like cells obtained from hESC by Zhang et al. 2009 were mono-hormonal, but just around $25 \%$ of obtained cells were producing insulin and expressing PDX1 [140]. Cells were also able to respond to the $\mathrm{KCl}$ and glucose stimulation by secretion of C-peptide [140]. According to the protocol proposed by Rezania et al. 2014 also mono-hormonal $\beta$-like cells were obtained. Additionally, to PDX1 and NKX6.1, they were showing MAFA expression, which is important for $\beta$-cells maturation [159]. Nevertheless, glucose-stimulated insulin secretion displayed by those cells was delayed and slower compared to human islets what suggest that obtained cells are functionally immature comparing to the human $\beta$-cells. However, when cells were transplanted to immunodeficient STZ-diabetic mice they were able to restore normal glucose level [141]. Pagliuca et al. 2014 in their protocol obtained stem cells-derived $\beta$-cells (SC- $\beta$ cells), which were expressing markers like adult $\beta$-cells, but there were still differences in the expression level. SC- $\beta$ cells were able to flux $\mathrm{Ca}^{2+}$ in response to glucose to a similar extent to mature $\beta$-cells and were able to package insulin into secretory granules. Additionally, cells transplanted to the diabetic mice were able to secrete insulin but on a lower level than human islets [133]. Nair et al. 2019 after modification of their previous protocol [134] managed to generate enriched $\beta$-clusters (eBC) from immature $\beta$-like cells [142]. They showed that the clustering of $\beta$-like cells has a positive impact on their maturation [160]. eBCs showed a response to glucose similar to human islets even though on the lower level. A significant and rapid increase in calcium influx after stimulation with high glucose and $\mathrm{KCl}$ was observed and what is also relevant the flux returned to baseline after glucose concentration was lowered. Mitochondria morphology of the eBCs was also different with the increase in the mitochondrial mass compared to the level observed for $\beta$-like cells. Another improvement was also noticed after eBCs transplantation into mice when C-peptide secretion could be detected as short as three days post-transplantation and was maintained for a long time [142]. In their protocol, Yoshihara et al. 2020 proposed activation of non-canonical WNT signaling as beneficial for metabolic maturation of islet-like organoids (HILO) obtained from differentiated $\beta$-like cells. After transplantation into diabetic NOD/SCID mice, HILOs were able to restore glucose homeostasis for more than six weeks. In HILOs, an increase in mitochondrial content was also observed, which suggested improvement in cells maturation [144]. Most likely delivery of the $\beta$-cells as clusters similar to human pancreatic islets is the most 
promising approach. As it was shown that it gives the best results in the case of the maturation of $\beta$-like cells, and allows to reach normoglycemia in a short time, as it takes place after cadaveric islets transplantation.

The first animal trials were also performed with the application of SC-derived islets or islet-like organoids. It was shown that conformal-coated human SC-derived islets were able to reverse diabetes in mice [161]. Promising results were also obtained with polymer encapsulated human SC-derived $\beta$-cells in mice [162]. Pre-clinical studies were also performed in the non-human primates by Vertex Farmaceuticals. Used islets-like organoids were able to decrease insulin intake by $60 \%$ [163].

\section{Available $\alpha$-Cell Differentiation Protocols}

Generating $\alpha$-cells from various types of stem cells has not yet gained the same popularity as generating insulin-producing cells. Nevertheless, there are indications that $\alpha$-cells play role in T1D etiology, especially considering the importance of $\alpha$-cells $\beta$-cells interactions $[164,165]$. Still, lots of work has been done in this area in the last 10 years. The most famous research was done by Rezania et al. in 2011 [166]. They developed a six-step differentiation protocol that allows conversing human embryonic stem cells into functional glucagon-producing cells. It is based on the native development of the endocrine pancreas. In the first step, they induced stem cell transformation into mesoendoderm by the addition of growth factors (Activin A., Wortmanin, and FGF2) for 3 days. Mesoendoderm cells were then differentiated into endoderm progenitors in the second step (FGF and Cyclopamine-KAAD). Endoderm progenitors were further transformed into foregut progenitors (step three) with the use of Cyclopamine-KAAD, Retinoic acid, FGF7, and NOGGIN as growth factors. In the fourth step, foregut progenitors were differentiated into endocrine precursors by the use of three growth factors (ALK5 inhibitor II, NOGGIN, and DAPT). The fifth step involved transformation into immature endocrine cells with ALK5 inhibitor II. The last step (fourth) consisted of cells maturation into $\alpha$-cells (in clusters with $\beta$-cells) and lasted for 7 days. Every step was confirmed by the expression of proper genetic markers. It was as follows: Mesoendoderm-CXCR4, FOXA2, SOX17; Endoderm progenitors-HNF4 $\alpha$, PDX1; Foregut progenitors-NGN3, HNF4 $\alpha$, PDX1; Endocrine precursors-NEUROD, NGN3, PAX4, PAX6, NKX2.2, ARX; Immature endocrine-GCG, INS, ARX; $\alpha$-cells-GCG, ARX.

Peterson et al. in 2020 proposed a protocol of differentiation of stem-cells derived $\alpha$-cells (SC- $\alpha$ ) [167]. They characterized two $\alpha$-cells maturation stages. The first in which cells were showing both insulin and glucagon expression (were further described as pre- $\alpha$ cells) and the second maturation stage, where cells were expressing just glucagon (SC- $\alpha$ cells). They described that lowering expressing the NKX6.1 by removing KGF, SANT-1, and introducing LDN during step four is crucial for redirecting differentiation into $\alpha$-cells. They showed that pre- $\alpha$ cells are able to maturate to mono-hormonal, glucagon secreting cells both in vitro and in vivo. They described that PDBu addition during step six is important for obtaining SC- $\alpha$ cells. According to this protocol they managed to obtain around $30 \%$ of SC- $\alpha$ cells that were secreting glucagon and were able to stop the secretion in response to the glucose.

\section{Immune-Related Aspects of T1D and Possible Applications of Stem Cells in Therapy}

Although molecular pathomechanism standing behind T1D remains not fully understood, several works point to disturbance in human leukocyte antigen (HLA) system expression in T1D patients [26,168,169]. HLA (or major histocompatibility complex, MHC) is a cluster of surface proteins pivotal in proper recognition of antigens by distinct types of lymphocytes T. All HLA-coding genes are located on chromosome 6 and are highly polymorphic which reflects in many variants of particular HLA protein which, in turn, occur in multiple combinations on cells [170-172]. Such a complex repertoire ensures flexibility and fine-tuning of the adaptive immune system. However, certain combinations of HLAs have been correlated to a higher risk of appearance of autoimmune disorders, such 
as T1D [173,174], rheumatoid arthritis [174], coeliac disease [175], etc. According to this knowledge, the cell replacement-based approach of T1D treatment must face the immune barrier issue of whether a patient will receive SC-derived- $\beta$ cells as either auto- or allograft. In the first case, reprogrammed cells will still be laden with invalid HLA repertoire which will lead to renewed auto-aggression. The second case will require immune suppression to prevent rejection of the graft. A promising solution to both scenarios would be to make transplanted cells immunologically inert. Works of many groups have suggested that such an effect would be possible with the inactivation of HLA genes in cells of interest. Of others, two approaches based on the inactivation of B2M and CIITA gene have been intensively examined [176-184]. B2M encodes $\beta$-2-microglobulin, a protein that forms heterodimers with HLA Class I proteins present on surface of nearly all nucleated cells in the body and responsible for the presentation of intracellular antigens $[170,185,186]$. CIITA gene encodes the transcription factor which activates expression of HLA Class II proteins presenting extracellular antigens and stimulating indirectly specific antibody-producing $B$ lymphocytes [170,187-189]. Altogether, double knock-out of B2M and CIITA genes leads to disabling of nearly all HLA proteins in the cell. However, some of the published results have led to the conclusion that the inactivation of HLA proteins alone will not be sufficient. Besides antigen presentation, the immune system distinguishes the host's own cells from "invaders" by the presence of particular protein markers on their surface. A very interesting tool for the creation of universal stem cell lines is genome editing, especially clustered regularly interspaced short palindromic repeats (CRISPR)/CRISPR-associated protein 9 (Cas9) seems to be very promising when it allows, in an easy and efficient way, introduce desired mutations (Figure 3). First attempt to ablate HLA class I with the application of CRISPR/Cas9 was done in hematopoietic stem cells where B2M was targeted [180]. In 2017, Hong et al. simultaneously knocked out $H L A-A,-B$, and $-C$ obtaining similar results as when $B 2 M$ was inactivated [190]. CRISPR/Cas9 was also used to knockout HLA-B in iPSCs what resulted in better immunocompatibility and what is important preserved differentiation capacity [191]. Gornalusse et al. in 2017 obtained modified iPSCs by the knockout of the B2M gene and overexpression of HLA-E single-chain dimers or trimers, such cells were not recognized by $\mathrm{CD}^{+}$T-cells and resistant to NK-mediated lysis [192]. In 2019, two groups presented results from stem cells with disrupted HLA proteins and additional overexpression of CD47 protein which is recognized by macrophages as a "don'teat-me" signal. Modified cells remained unrecognized by the immune system for a long time after transplantation to mice and retained pluripotent properties [193,194]. In the same year, Xu et al. 2019 performed the knockout of $H L A-A,-B$, and CIITA in the iPSCs, and at the same time knocked out just one allele of $H L A-C$ obtaining the monoallelic line. Non-classical HLA class I (HLA-E, -F, -G) remained unmodified. As a result, obtained cells were not recognized by T cells and NK cells. Authors estimated that around 12 monoallelic HLA-C-retained iPSCs lines would be sufficient to cover more than $90 \%$ of the world population [195]. Another approach was used by Lei Shi et al. 2020, where B2M was knocked out with CRISPR/Cas9 what allowed to avoid T-cell-directed immune response and at the same time overexpression of Beta2m-HLA-G1 fusion protein was performed what caused inhibition of NK cells mediated cytolysis [196]. Such combined manipulation would be a suitable solution in cell-replacement approaches for T1D. On the other hand, as transformed cells become out of any organismal control, it would raise an extremely challenging long-term safety issue. It has been previously shown that iPSCs may represent a tendency to tumorigenicity due to point mutations occurring as a consequence of invalid epigenetic reprogramming of cells $[197,198]$. Additionally, re-differentiated iPSC may not fully undergo differentiation or uncontrollably reverse the differentiation fate and turn back into a pluripotent state followed by teratoma formation $[199,200]$. All these potential risks give rise to a high need to provide an efficient self-control tool and an inducible safety switch that enables controlled apoptosis in case of emergency. There are known several approaches based on the suicide gene technique. Literally, it assumes the introduction of a gene variant that expresses a protein prone to the exogenous agent to the cell genome. Since 
2000, strategies based on CD20 overexpression [201], ganciclovir-metabolizing HSV-TK viral kinase [202], or proapoptotic caspase- 9 with a caspase-recruiting domain substituted to mutated drug-binding domain from the human FK506-binding protein (iCASP9) sensitive to rimiducid (AP1903) $[203,204]$ have been presented. Although the two first approaches may exhibit side effects caused by off-targeting of anti-CD20 antibody to native CD20positive cell populations or required instant ganciclovir treatment of herpes simplex virus infection, respectively, the latter approach is thought to be promising as several works have shown [205-207]. Recently, the iCASP9 system has been improved by precise, targeted location in the genome in intron 1 of the PPP1R12C gene (AAVS1 locus) [208]. The AAVS1 locus is well characterized, and gene editing of this region has been shown to not cause any aberrations in self-renewal or pluripotency of hESCs and iPSCs [209-211]. An approach worth considering would be incorporation into the genetically stable region (i.e., aforementioned AAVS1 locus), a cassette encoding apoptotic trigger by which expression would be conditioned by the expression of a particular oncogenic marker. As such, a considerable construct could be composed of an open reading frame for P53 protein, a well-described pro-apoptotic factor, under promoter inhibited by repressor protein. In turn, the transcript of the repressor could be comprised with binding sites for microRNA-21 by which expression has been shown to be significantly elevated in many types of tumors. Such a negative feedback loop could allow the transformed cells to initiate programmed death as an only uncontrolled expression of oncogenic marker occurs.
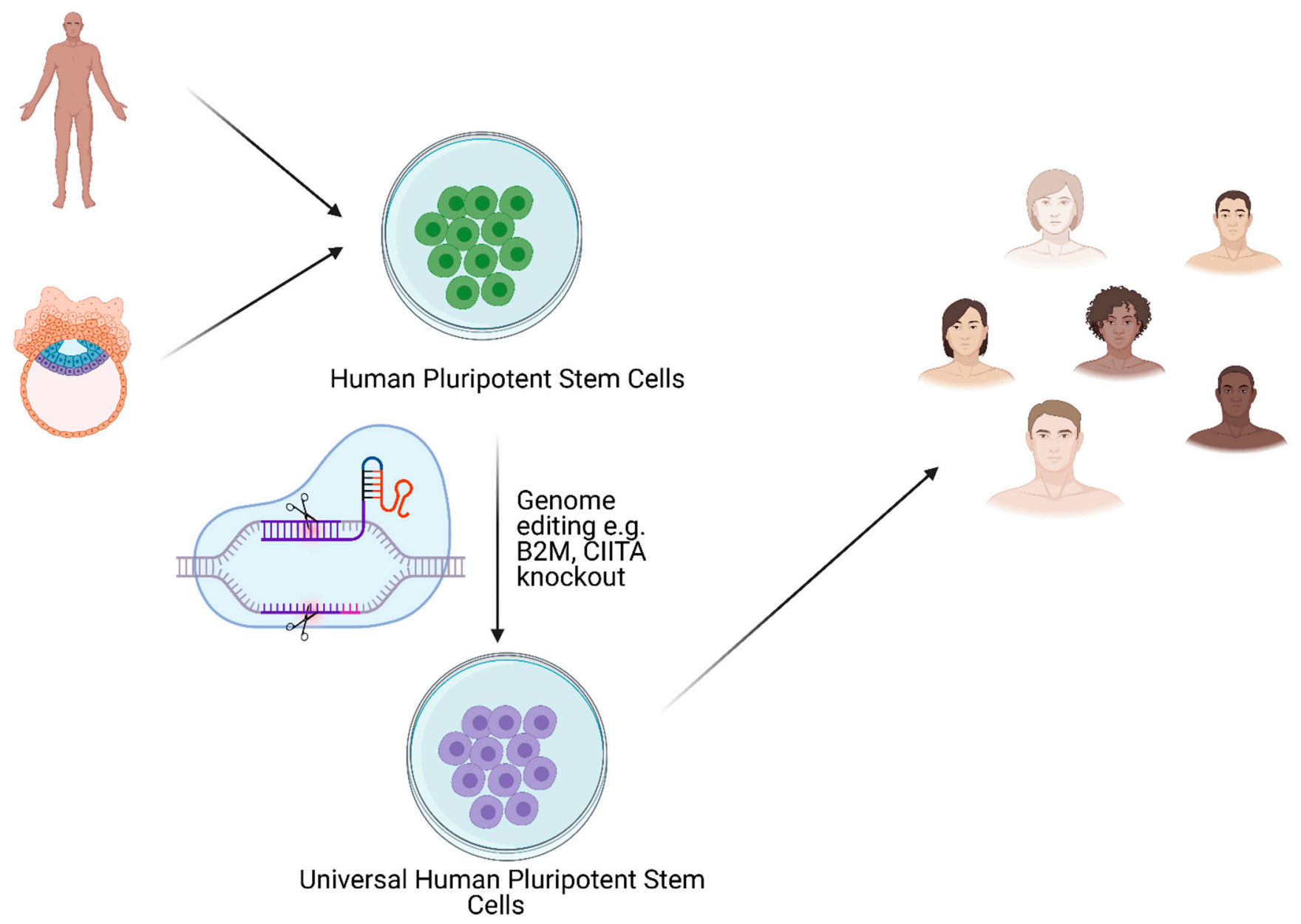

Figure 3. Possible approach for obtaining universal human pluripotent stem cell line. Created with BioRender.com accessed on 17 June 2021. 


\section{Artificial Islets and 3D Bioprinted Pancreas for T1D Treatment}

Producing $\alpha$ - and $\beta$-cells from any kind of stem cells will not be a full solution for the treatment of diabetes. Recent works suggest that interplay between cells within pancreatic islets plays a role in the proper reaction for glucose stimuli [212-218]. Cells within a 3D structure responded much better to the change of glucose level in GSIS tests. Currently, there are attempts to develop functional in vitro models of pancreatic islets in which the cellular microenvironment is fully preserved [219-221]. Using the issues of microflow and biomaterial engineering, the possibility of culturing and monitoring cells in a permeable 3D microenvironment was demonstrated. Combining different types of cells with each other, which are then suspended in biologically appropriate protein hydrogels, allows the formation of spatial tissue systems. In such models, cells interact with each other and the protein hydrogel, which is their barrier, is also a representation of their native environment [222]. In the case of pancreatic islets, attention should be paid to the islets of the pancreas are composed of different types of endocrine cells, their micro-vascularization is also important, which is crucial for adequate glucose homeostasis $[223,224]$. The microfluidic method seems to be the most appropriate and precise method for the encapsulation of single cells in biological hydrogels having the ability to cross-link under given physical and chemical conditions [225-227]. An important aspect of such a technological process is the possibility of optimizing the encapsulation parameters (shell thickness, hydrogel porosity), which can be modified in terms of selective permeability, as well as the size of the micro-organ produced and the number of cells used to produce them, which is extremely important when trying to create micro-vascularization $[219,228]$. Those parameters are usually optimized in the lab scale, the next challenge is switching to the industrial scale. The 3D bioprinting can help to overcome some of those obstacles, because of the proper distribution of the cells in the scaffold and the hypoxia improved by the vascularization [229].

Reproducing of islets microenvironment and producing even "perfect artificial islets" will not solve the problem of diabetes as transplantation of pancreatic islets is at the crossroads due to imperfect transplantation results. It is unlikely to think that the transplantation of artificial islets will produce better results. If we want to recreate the natural environment for islets with extracellular matrix and vasculature, it seems that the 3D bioprinting technique may be a solution for that problems, while it allows creating organs in fully controlled in vitro conditions. This technology allows bioprinting with the viable cells obtained from the cell cultures. Many aspects should be optimized to obtain a functional bionic organ. The first important aspect is the choice of proper bioprinting method. Nowadays, four main bioprinting methods are available: micro-extrusion [230], inkjet [231], laser [232], and stereolithography (SLA) [233]. The most popular in the field of tissue engineering are currently extrusion-based methods and SLA [234]. The other important aspects which should be thoughtfully evaluated are, the cell's concentration in the bioink and proper bioprinting conditions, like pressure, printing speed, or crosslinking method [234]. So far there are not many published reports describing applications of 3D bioprinting for T1D treatment. In the first try, Marchioli et al. successfully used rat $\beta$-cell line and human, and mice islets to print in the designed 3D scaffold applying alginate-based bioinks [235]. They did not report changes in the cell's viability or morphology. Additionally, rat islets were printed with the application of 3D bioprinting technology, the impact on the cells viability, morphology, and functionality was small [236]. In 2019, the Polish team lead by M. Wszoła 3D bioprinted a bionic pancreas with the full vasculature using pancreatic islets, bioinks with the extracellular matrix, and endothelial cells which had a diameter of $3 \times 3$, $5 \times 5 \mathrm{~cm}^{3}$ and had 600,000 islets equivalents, which produced insulin (patent proceeding, manuscript in preparation). The decellularized extracellular matrix obtained from the pig's pancreas was used for the preparation of bioinks. In the obtained product detergent was not detected, a low level of lipids was present, and high content of collagen was shown [237]. Evaluation of the bioprinting conditions was performed and the right ratio of the islets to bioink was estimated, the UV crosslinking time and the pressure applied to extrude 
the bioink's fiber was assessed. The islets inside the obtained bionic pancreas were viable and their functionality was proved by the glucose-stimulated insulin secretion assay [238]. Magnetic resonance imaging showed a perfect projection of planned to received results.

Soft tissue engineering in the future could solve the problem of the organ shortage for transplantation. Now several research teams around the world are focused on the investigation of the 3D bioprinting technology with the application of $\alpha$ - and $\beta$-cells, pancreatic islets, or whole bioprinted pancreas for T1D treatment. In the future, universal, stem cell-derived $\alpha$ - and $\beta$-cells could be a source of the cells for 3D bioprinted pancreas. Such an artificial organ could be transplanted into any T1D patient without the need for immunosuppressive therapy. This could be a perfect solution for the patient with T1D.

At this point, it is worth pointing to the need for a multidisciplinary approach to the subject. Although individual technologies, such as the use of microfluidics to produce $3 \mathrm{D}$ biological systems $[239,240]$, the production of protein hydrogels to recreate the native environment for the cells used, or the transformation of stem cells [141,166], and 3D bioprinting technology for recreating 3D structure or organ, as well as biodegradation of tissue systems, are the goal of many scientists, the most optimal approach seems to be to combine all these activities into one technology that allows the creation of functional, neutral for the organism of recipients, bionic pancreas.

Author Contributions: Conceptualization: M.W.; M.K.; writing—original draft preparation: M.W., M.K., P.C., M.G.; writing—review and editing: M.W., M.K., D.N.; visualization: D.N.; supervision: M.W., M.K. All authors have read and agreed to the published version of the manuscript.

Funding: This study was financially supported by The National Centre for Research and Development STRATEGMED3/305813/2/NCBR/2017.

Conflicts of Interest: The authors declare no conflict of interest.

\section{References}

1. Martin, G.R. Isolation of a Pluripotent Cell Line from Early Mouse Embryos Cultured in Medium Conditioned by Teratocarcinoma Stem Cells. Proc. Natl. Acad. Sci. USA 1981, 78, 7634-7638. [CrossRef] [PubMed]

2. Evans, M.J.; Kaufman, M.H. Establishment in Culture of Pluripotential Cells from Mouse Embryos. Nature 1981, $292,154-156$. [CrossRef] [PubMed]

3. Thomson, J.A. Embryonic Stem Cell Lines Derived from Human Blastocysts. Science 1998, 282, 1145-1147. [CrossRef] [PubMed]

4. Singh, V.K.; Kalsan, M.; Kumar, N.; Saini, A.; Chandra, R. Induced Pluripotent Stem Cells: Applications in Regenerative Medicine, Disease Modeling, and Drug Discovery. Front. Cell Dev. Biol. 2015, 3. [CrossRef]

5. Potten, C.S.; Loeffler, M. Stem Cells: Attributes, Cycles, Spirals, Pitfalls and Uncertainties: Lessons for and from the Crypt. Development 1990, 110. [CrossRef]

6. Yang, J.; Liu, H.; Sun, H.; Wang, Z.; Zhang, R.; Liu, Y.; Zhang, Q.; Zhang, S.; Zhang, J.; Shi, C.; et al. Construction of Induced Pluripotent Stem Cell Line (ZZUi0017-A) from the Fibroblast Cells of a Female Patient with CACNA1A Mutation by Unintegrated Reprogramming Approach. Stem Cell Res. 2020, 48. [CrossRef]

7. Wobus, A.M.; Boheler, K.R. Embryonic Stem Cells: Prospects for Developmental Biology and Cell Therapy. Physiol. Rev. 2005, 85, 635-678. [CrossRef]

8. Valetdinova, K.R.; Maretina, M.A.; Vyatkin, Y.V.; Perepelkina, M.P.; Egorova, A.A.; Baranov, V.S.; Kiselev, A.V.; Gershovich, P.M.; Zakian, S.M. Generation of Three Duchenne Muscular Dystrophy Patient-Derived Induced Pluripotent Stem Cell (IPSC) Lines ICGi002-A, ICGi002-B and ICGi002-C. Stem Cell Res. 2020, 48. [CrossRef]

9. Wilmut, I.; Schnieke, A.E.; McWhir, J.; Kind, A.J.; Campbell, K.H.S. Viable Offspring Derived from Fetal and Adult Mammalian Cells. Nature 1997, 385, 810-813. [CrossRef]

10. Murry, C.E.; Keller, G. Differentiation of Embryonic Stem Cells to Clinically Relevant Populations: Lessons from Embryonic Development. Cell 2008, 132, 661-680. [CrossRef]

11. Vazin, T.; Freed, W.J. Human Embryonic Stem Cells: Derivation, Culture, and Differentiation: A Review. Restor. Neurol. Neurosci. 2010, 28, 589-603. [CrossRef]

12. González, F.; Boué, S.; Belmonte, J.C.I. Methods for Making Induced Pluripotent Stem Cells: Reprogramming à La Carte. Nat. Rev. Genet. 2011, 12, 231-242. [CrossRef]

13. Schlaeger, T.M.; Daheron, L.; Brickler, T.R.; Entwisle, S.; Chan, K.; Cianci, A.; DeVine, A.; Ettenger, A.; Fitzgerald, K.; Godfrey, M.; et al. A Comparison of Non-Integrating Reprogramming Methods. Nat. Biotechnol. 2015, 33, 58-63. [CrossRef] [PubMed] 
14. Shafa, M.; Yang, F.; Fellner, T.; Rao, M.S.; Baghbaderani, B.A. Human-Induced Pluripotent Stem Cells Manufactured Using a Current Good Manufacturing Practice-Compliant Process Differentiate into Clinically Relevant Cells from Three Germ Layers. Front. Med. 2018, 5, 1-12. [CrossRef]

15. Cierpka-Kmiec, K.; Wronska, A.; Kmiec, Z. In Vitro Generation of Pancreatic $\beta$-Cells for Diabetes Treatment. I. $\beta$-like Cells Derived from Human Pluripotent Stem Cells. Folia Histochem. Cytobiol. 2019, 57, 1-14. [CrossRef] [PubMed]

16. Pellegrini, S.; Piemonti, L.; Sordi, V. Pluripotent Stem Cell Replacement Approaches to Treat Type 1 Diabetes. Curr. Opin. Pharmacol. 2018, 43, 20-26. [CrossRef]

17. Millman, J.R.; Xie, C.; Van Dervort, A.; Gürtler, M.; Pagliuca, F.W.; Melton, D.A. Generation of Stem Cell-Derived $\beta$-Cells from Patients with Type 1 Diabetes. Nat. Commun. 2016, 7. [CrossRef]

18. Sneddon, J.B.; Tang, Q.; Stock, P.; Bluestone, J.A.; Roy, S.; Desai, T.; Hebrok, M. Stem Cell Therapies for Treating Diabetes: Progress and Remaining Challenges. Cell Stem Cell 2018, 22, 810-823. [CrossRef]

19. Mesenchymal Stem Cell-Based Therapy for Type 1 Diabetes-Hao Wu-Discovery Medicine. Available online: https://www. discoverymedicine.com/Hao-Wu/2014/03/07/mesenchymal-stem-cell-based-therapy-for-type-1-diabetes/ (accessed on 20 August 2020).

20. Liese, A.D. The Burden of Diabetes Mellitus among US Youth: Prevalence Estimates from the SEARCH for Diabetes in Youth Study: SEARCH for Diabetes in Youth Study Group. Pediatrics 2006, 118, 1510-1518. [CrossRef] [PubMed]

21. Shih, H.P.; Wang, A.; Sander, M. Pancreas Organogenesis: From Lineage Determination to Morphogenesis. Annu. Rev. Cell Dev. Biol. 2013, 29, 81-105. [CrossRef]

22. Guney, M.A.; Gannon, M. Pancreas Cell Fate. Birth Defects Res. Part C Embryo Today Rev. 2009, 87, 232-248. [CrossRef]

23. American Diabetes Association. Diagnosis and Classification of Diabetes Mellitus. Diabetes Care 2009, 32. [CrossRef]

24. Maahs, D.M.; West, N.A.; Lawrence, J.M.; Mayer-Davis, E.J. Epidemiology of Type 1 Diabetes. Endocrinol. Metab. Clin. N. Am. 2010, 39, 481-497. [CrossRef]

25. Mehers, K.L.; Gillespie, K.M. The Genetic Basis for Type 1 Diabetes. Br. Med. Bull. 2008, 88, 115-129. [CrossRef]

26. Niedźwiedzka-Rystwej, P.; Wołącewicz, M.; Cywoniuk, P.; Klak, M.; Wszoła, M. Crosstalk Between Immunity System Cells and Pancreas. Transformation of Stem Cells Used in the 3D Bioprinting Process as a Personalized Treatment Method for Type 1 Diabetes. Arch. Immunol. Ther. Exp. 2020, 68, 1-9. [CrossRef]

27. Diabetes Control and Complications Trial Research Group; Nathan, D.M.; Genuth, S.; Lachin, J.; Cleary, P.; Crofford, O.; Davis, M.; Rand, L.; Siebert, C. The Effect of Intensive Treatment of Diabetes on the Development and Progression of Long-Term Complications in Insulin-Dependent Diabetes Mellitus. N. Engl. J. Med. 1993, 329, 977-986. [CrossRef]

28. Lachin, J.M.; Genuth, S.; Cleary, P.; Davis, M.D.; Nathan, D.M. Retinopathy and Nephropathy in Patients with Type I Diabetes Four Years after a Trial of Intensive Therapy. N. Engl. J. Med. 2000, 342, 381-389. [CrossRef]

29. Diabetes Control and Complications Trial Research Group. The Effect of Intensive Treatment of Diabetes on the Development and Progression of Long-Term Complications in Insulin-Dependent Diabetes Mellitus. Endocrinologist 1994, 4, 154. [CrossRef]

30. Nathan, D.M. Long-Term Complications of Diabetes Mellitus. N. Engl. J. Med. 1993, 328, 1676-1685. [CrossRef]

31. Cryer, P.E. The Barrier of Hypoglycemia in Diabetes. Diabetes 2008, 57, 3169-3176. [CrossRef]

32. Kawecki, D.; Kwiatkowski, A.; Michalak, G.; Sawicka-Grzelak, A.; Mlynarczyk, A.; Sokol-Leszczynska, B.; Kot, K.; Czerwinski, J.; Lisik, W.; Bieniasz, M.; et al. Etiologic Agents of Bacteremia in the Early Period After Simultaneous Pancreas-Kidney Transplantation. Transplant. Proc. 2009, 41, 3151-3153. [CrossRef]

33. Michalak, G.; Kwiatkowski, A.; Bieniasz, M.; Meszaros, J.; Czerwinski, J.; Wszola, M.; Nosek, R.; Ostrowski, K.; Chmura, A.; Danielewicz, R.; et al. Infectious Complications after Simultaneous Pancreas-Kidney Transplantation. Transplant. Proc. 2005, 37, 3560-3563. [CrossRef]

34. Michalak, G.; Kwiatkowski, A.; Czerwinski, J.; Chmura, A.; Wszola, M.; Nosek, R.; Ostrowski, K.; Danielewicz, R.; Lisik, W.; Adadynski, L.; et al. Surgical Complications of Simultaneous Pancreas-Kidney Transplantation: A 16-Year-Experience at One Center. Transplant. Proc. 2005, 37, 3555-3557. [CrossRef]

35. Shapiro, A.M.J.; Lakey, J.R.T.; Ryan, E.A.; Korbutt, G.S.; Toth, E.; Warnock, G.L.; Kneteman, N.M.; Rajotte, R.V. Islet Transplantation in Seven Patients with Type 1 Diabetes Mellitus Using a Glucocorticoid-Free Immunosuppressive Regimen. N. Engl. J. Med. 2000, 343, 230-238. [CrossRef]

36. Shapiro, A.M.J.; Ricordi, C.; Hering, B.J.; Auchincloss, H.; Lindblad, R.; Robertson, R.P.; Secchi, A.; Brendel, M.D.; Berney, T.; Brennan, D.C.; et al. International Trial of the Edmonton Protocol for Islet Transplantation. N. Engl. J. Med. 2006, 355, 1318-1330. [CrossRef]

37. TransEndoscopic Gastric SubMucosa Islet Transplantation (EGSM-ITx) in Pigs with Streptozotocine Induced Diabetes-Technical Aspects of the Procedure-Preliminary Report-PubMed. Available online: https://pubmed.ncbi.nlm.nih.gov/19487794/ (accessed on 18 August 2020).

38. Wszola, M.; Berman, A.; Ostaszewska, A.; Gorski, L.; Serwanska-Swietek, M.; Gozdowska, J.; Bednarska, K.; Krajewska, M.; Lipinska, A.; Chmura, A.; et al. Islets Allotransplantation Into Gastric Submucosa in a Patient with Portal Hypertension: 4-Year Follow-Up. Transplant. Proc. 2018, 50, 1910-1913. [CrossRef] [PubMed]

39. Wszola, M.; Berman, A.; Gorski, L.; Ostaszewska, A.; Serwanska-Swietek, M.; Krajewska, M.; Lipinska, A.; Chmura, A.; Kwiatkowski, A. Endoscopic Islet Autotransplantation into Gastric Submucosa-1000-Day Follow-up of Patients. Transplant. Proc. 2018, 50, 2119-2123. [CrossRef] 
40. Ye, Q.; Sung, T.C.; Yang, J.M.; Ling, Q.D.; He, Y.; Higuchi, A. Generation of Universal and Hypoimmunogenic Human Pluripotent Stem Cells. Cell Prolif. 2020, 53, 1-11. [CrossRef]

41. Thomson, J.A.; Kalishman, J.; Golos, T.G.; Durning, M.; Harris, C.P.; Becker, R.A.; Hearn, J.P. Isolation of a Primate Embryonic Stem Cell Line. Proc. Natl. Acad. Sci. USA 1995, 92, 7844-7848. [CrossRef]

42. Carpenter, M.K.; Rosler, E.; Rao, M.S. Characterization and Differentiation of Human Embryonic Stem Cells. Cloning Stem Cells 2003, 5, 79-88. [CrossRef] [PubMed]

43. Klimanskaya, I.; Chung, Y.; Becker, S.; Lu, S.J.; Lanza, R. Human Embryonic Stem Cell Lines Derived from Single Blastomeres. Nature 2006, 444, 481-485. [CrossRef] [PubMed]

44. Baylis, F. Human Embryonic Stem Cell Lines: The Ethics of Derivation. J. Obstet. Gynaecol. Can. 2002, 24, 159-163. [CrossRef]

45. Hovatta, O.; Stojkovic, M.; Nogueira, M.; Varela-Nieto, I. European Scientific, Ethical, and Legal Issues on Human Stem Cell Research and Regenerative Medicine. Stem Cells 2010, 28, 1005-1007. [CrossRef] [PubMed]

46. Chung, Y.; Klimanskaya, I.; Becker, S.; Li, T.; Maserati, M.; Lu, S.J.; Zdravkovic, T.; Ilic, D.; Genbacev, O.; Fisher, S.; et al. Human Embryonic Stem Cell Lines Generated without Embryo Destruction. Cell Stem Cell 2008, 2, 113-117. [CrossRef]

47. Koivisto, H.; Hyvärinen, M.; Strömberg, A.M.; Inzunza, J.; Matilainen, E.; Mikkola, M.; Hovatta, O.; Teerijoki, H. Cultures of Human Embryonic Stem Cells: Serum Replacement Medium or Serum-Containing Media and the Effect of Basic Fibroblast Growth Factor. Reprod. Biomed. Online 2004, 9, 330-337. [CrossRef]

48. Carpenter, M.K.; Rosler, E.S.; Fisk, G.J.; Brandenberger, R.; Ares, X.; Miura, T.; Lucero, M.; Rao, M.S. Properties of Four Human Embryonic Stem Cell Lines Maintained in a Feeder-Free Culture System. Dev. Dyn. Off. Publ. Am. Assoc. Anat. 2004, 229, 243-258. [CrossRef]

49. Inzunza, J.; Gertow, K.; Strömberg, M.A.; Matilainen, E.; Blennow, E.; Skottman, H.; Wolbank, S.; Ährlund-Richter, L.; Hovatta, O. Derivation of Human Embryonic Stem Cell Lines in Serum Replacement Medium Using Postnatal Human Fibroblasts as Feeder Cells. Stem Cells 2005, 23, 544-549. [CrossRef]

50. Rodin, S.; Antonsson, L.; Niaudet, C.; Simonson, O.E.; Salmela, E.; Hansson, E.M.; Domogatskaya, A.; Xiao, Z.; Damdimopoulou, P.; Sheikhi, M.; et al. Clonal Culturing of Human Embryonic Stem Cells on Laminin-521/E-Cadherin Matrix in Defined and Xeno-Free Environment. Nat. Commun. 2014, 5, 1-13. [CrossRef]

51. Harrison, D.E.; Stone, M.; Astle, C.M. Effects of Transplantation on the Primitive Immunohematopoietic Stem Cell. J. Exp. Med. 1990, 172, 431-437. [CrossRef]

52. Murrell, W.; Féron, F.; Wetzig, A.; Cameron, N.; Splatt, K.; Bellette, B.; Bianco, J.; Perry, C.; Lee, G.; Mackay-Sim, A. Multipotent Stem Cells from Adult Olfactory Mucosa. Dev. Dyn. 2005, 233, 496-515. [CrossRef] [PubMed]

53. Liu, S.; Dontu, G.; Wicha, M.S. Mammary Stem Cells, Self-Renewal Pathways, and Carcinogenesis. Breast Cancer Res. 2005, 7, 86-95. [CrossRef] [PubMed]

54. Rezza, A.; Sennett, R.; Rendl, M. Adult Stem Cell Niches. Cellular and Molecular Components. Curr. Top. Dev. Biol. 2014, 107, 333-372. [PubMed]

55. Friedenstein, A.J.; Chailakhyan, R.K.; Latsinik, N.V.; Panasyvk, A.F.; Keiliss-Borok, I.V. Stromal Cells Responsible for Transferring the Microenvironment of the Hemopoietic Tissues: Cloning In Vitro and Retransplantation In Vivo. Transplantation 1974, 17, 331-340. [CrossRef] [PubMed]

56. Sousa, B.R.; Parreira, R.C.; Fonseca, E.A.; Amaya, M.J.; Tonelli, F.M.P.; Lacerda, S.M.S.N.; Lalwani, P.; Santos, A.K.; Gomes, K.N.; Ulrich, H.; et al. Human Adult Stem Cells from Diverse Origins: An Overview from Multiparametric Immunophenotyping to Clinical Applications. Cytom. Part A 2014, 85, 43-77. [CrossRef]

57. Zuk, P.A.; Zhu, M.; Mizuno, H.; Huang, J.; Futrell, J.W.; Katz, A.J.; Benhaim, P.; Lorenz, H.P.; Hedrick, M.H. Multilineage Cells from Human Adipose Tissue: Implications for Cell-Based Therapies. Tissue Eng. 2001, 7, 211-228. [CrossRef]

58. Pittenger, M.F.; Mackay, A.M.; Beck, S.C.; Jaiswal, R.K.; Douglas, R.; Mosca, J.D.; Moorman, M.A.; Simonetti, D.W.; Craig, S.; Marshak, D.R. Multilineage Potential of Adult Human Mesenchymal Stem Cells. Science 1999, 284, 143-147. [CrossRef]

59. Ha, D.H.; Kim, H.; Lee, J.; Kwon, H.H.; Park, G.-H.; Yang, S.H.; Jung, J.Y.; Choi, H.; Lee, J.H.; Sung, S.; et al. Mesenchymal Stem/Stromal Cell-Derived Exosomes for Immunomodulatory Therapeutics and Skin Regeneration. Cells 2020, 9, 1157. [CrossRef]

60. Börger, V.; Bremer, M.; Ferrer-Tur, R.; Gockeln, L.; Stambouli, O.; Becic, A.; Giebel, B. Mesenchymal Stem/Stromal Cell-Derived Extracellular Vesicles and Their Potential as Novel Immunomodulatory Therapeutic Agents. Int. J. Mol. Sci. 2017, 18, 1450. [CrossRef]

61. Maacha, S.; Sidahmed, H.; Jacob, S.; Gentilcore, G.; Calzone, R.; Grivel, J.C.; Cugno, C. Paracrine Mechanisms of Mesenchymal Stromal Cells in Angiogenesis. Stem Cells Int. 2020, 2020. [CrossRef]

62. Poggi, A.; Zocchi, M.R. Immunomodulatory Properties of Mesenchymal Stromal Cells: Still Unresolved "Yin and Yang". Curr. Stem Cell Res. Ther. 2018, 14, 344-350. [CrossRef]

63. Goodarzi, P.; Larijani, B.; Alavi-Moghadam, S.; Tayanloo-Beik, A.; Mohamadi-Jahani, F.; Ranjbaran, N.; Payab, M.; Falahzadeh K.; Mousavi, M.; Arjmand, B. Mesenchymal stem cells-derived exosomes for wound regeneration. In Advances in Experimental Medicine and Biology; Springer: New York, NY, USA, 2018; Volume 1119, pp. 119-131.

64. Fierabracci, A.; Del Fattore, A.; Luciano, R.; Muraca, M.; Teti, A.; Muraca, M. Recent Advances in Mesenchymal Stem Cell Immunomodulation: The Role of Microvesicles. Cell Transplant. 2015, 24, 133-149. [CrossRef] 
65. Prabakar, K.R.; Domínguez-Bendala, J.; Damaris Molano, R.; Pileggi, A.; Villate, S.; Ricordi, C.; Inverardi, L. Generation of GlucoseResponsive, Insulin-Producing Cells from Human Umbilical Cord Blood-Derived Mesenchymal Stem Cells. Cell Transplant. 2012, 21, 1321-1339. [CrossRef]

66. Shivakumar, S.B.; Lee, H.J.; Son, Y.B.; Bharti, D.; Ock, S.A.; Lee, S.L.; Kang, Y.H.; Park, B.W.; Rho, G.J. In Vitro Differentiation of Single Donor Derived Human Dental Mesenchymal Stem Cells into Pancreatic $\beta$ Cell-like Cells. Biosci. Rep. 2019, 39. [CrossRef]

67. Kanafi, M.M.; Rajeshwari, Y.B.; Gupta, S.; Dadheech, N.; Nair, P.D.; Gupta, P.K.; Bhonde, R.R. Transplantation of Islet-like Cell Clusters Derived from Human Dental Pulp Stem Cells Restores Normoglycemia in Diabetic Mice. Cytotherapy 2013, 15, 1228-1236. [CrossRef]

68. Guo, Q.S.; Zhu, M.Y.; Wang, L.; Fan, X.J.; Lu, Y.H.; Wang, Z.W.; Zhu, S.J.; Wang, Y.; Huang, Y. Combined Transfection of the Three Transcriptional Factors, PDX-1, NeuroD1, and MafA, Causes Differentiation of Bone Marrow Mesenchymal Stem Cells into Insulin-Producing Cells. Exp. Diabetes Res. 2012, 2012. [CrossRef]

69. Govindasamy, V.; Ronald, V.S.; Abdullah, A.N.; Ganesan Nathan, K.R.; Aziz, Z.A.C.A.; Abdullah, M.; Musa, S.; Abu Kasim, N.H.; Bhonde, R.R. Differentiation of Dental Pulp Stem Cells into Islet-like Aggregates. J. Dent. Res. 2011, 90, 646-652. [CrossRef]

70. Phadnis, S.M.; Joglekar, M.V.; Dalvi, M.P.; Muthyala, S.; Nair, P.D.; Ghaskadbi, S.M.; Bhonde, R.R.; Hardikar, A.A. Human Bone Marrow-Derived Mesenchymal Cells Differentiate and Mature into Endocrine Pancreatic Lineage In Vivo. Cytotherapy 2011, 13, 279-293. [CrossRef] [PubMed]

71. Timper, K.; Seboek, D.; Eberhardt, M.; Linscheid, P.; Christ-Crain, M.; Keller, U.; Müller, B.; Zulewski, H. Human Adipose Tissue-Derived Mesenchymal Stem Cells Differentiate into Insulin, Somatostatin, and Glucagon Expressing Cells. Biochem. Biophys. Res. Commun. 2006, 341, 1135-1140. [CrossRef] [PubMed]

72. Lechner, A.; Yang, Y.-G.; Blacken, R.A.; Wang, L.; Nolan, A.L.; Habener, J.F. No Evidence for Significant Transdifferentiation of Bone Marrow into Pancreatic-Cells In Vivo. Diabetes 2004, 53. [CrossRef] [PubMed]

73. Choi, J.B.; Uchino, H.; Azuma, K.; Iwashita, N.; Tanaka, Y.; Mochizuki, H.; Migita, M.; Shimada, T.; Kawamori, R.; Watada, H. Little Evidence of Transdifferentiation of Bone Marrow-Derived Cells into Pancreatic Beta Cells. Diabetologia 2003, 46, 1366-1374. [CrossRef]

74. Ezquer, F.; Ezquer, M.; Contador, D.; Ricca, M.; Simon, V.; Conget, P. The Antidiabetic Effect of Mesenchymal Stem Cells Is Unrelated to Their Transdifferentiation Potential but to Their Capability to Restore Th1/Th2 Balance and to Modify the Pancreatic Microenvironment. Stem Cells 2012, 30, 1664-1674. [CrossRef]

75. Dave, S.D.; Vanikar, A.V.; Trivedi, H.L.; Thakkar, U.G.; Gopal, S.C.; Chandra, T. Novel Therapy for Insulin-Dependent Diabetes Mellitus: Infusion of in Vitro-Generated Insulin-Secreting Cells. Clin. Exp. Med. 2015, 15, 41-45. [CrossRef] [PubMed]

76. Thakkar, U.G.; Trivedi, H.L.; Vanikar, A.V.; Dave, S.D. Insulin-Secreting Adipose-Derived Mesenchymal Stromal Cells with Bone Marrow-Derived Hematopoietic Stem Cells from Autologous and Allogenic Sources for Type 1 Diabetes Mellitus. Cytotherapy 2015, 17, 940-947. [CrossRef]

77. Dang, L.T.T.; Bui, A.N.T.; Le-Thanh Nguyen, C.; Truong, N.C.; van Bui, A.T.; Kim, N.P.; Truong, K.D.; van Pham, P. Intravenous infusion of human adipose tissue-derived mesenchymal stem cells to treat type 1 diabetic mellitus in mice: An evaluation of grafted cell doses. In Advances in Experimental Medicine and Biology; Springer: New York, NY, USA, 2018; Volume 1083, pp. 145-156.

78. Li, L.; Hui, H.; Jia, X.; Zhang, J.; Liu, Y.; Xu, Q.; Zhu, D. Infusion with Human Bone Marrow-Derived Mesenchymal Stem Cells Improves $\beta$-Cell Function in Patients and Non-Obese Mice with Severe Diabetes. Sci. Rep. 2016, 6. [CrossRef]

79. Yaochite, J.N.U.; Caliari-Oliveira, C.; de Souza, L.E.B.; Neto, L.S.; Palma, P.V.B.; Covas, D.T.; Malmegrim, K.C.R.; Donadi, E.A. Therapeutic Efficacy and Biodistribution of Allogeneic Mesenchymal Stem Cells Delivered by Intrasplenic and Intrapancreatic Routes in Streptozotocin-Induced Diabetic Mice. Stem Cell Res. Ther. 2015, 6. [CrossRef] [PubMed]

80. Kerby, A.; Jones, E.S.; Jones, P.M.; King, A.J. Co-Transplantation of Islets with Mesenchymal Stem Cells in Microcapsules Demonstrates Graft Outcome Can Be Improved in an Isolated-Graft Model of Islet Transplantation in Mice. Cytotherapy 2013, 15, 192-200. [CrossRef] [PubMed]

81. Madec, A.M.; Mallone, R.; Afonso, G.; Abou Mrad, E.; Mesnier, A.; Eljaafari, A.; Thivolet, C. Mesenchymal Stem Cells Protect NOD Mice from Diabetes by Inducing Regulatory T Cells. Diabetologia 2009, 52, 1391-1399. [CrossRef] [PubMed]

82. Lee, R.H.; Seo, M.J.; Reger, R.L.; Spees, J.L.; Pulin, A.A.; Olson, S.D.; Prockop, D.J. Multipotent Stromal Cells from Human Marrow Home to and Promote Repair of Pancreatic Islets and Renal Glomeruli in Diabetic NODscid Mice. Proc. Natl. Acad. Sci. USA 2006, 83. [CrossRef]

83. Chen, J.; Chen, J.; Cheng, Y.; Fu, Y.; Zhao, H.; Tang, M.; Zhao, H.; Lin, N.; Shi, X.; Lei, Y.; et al. Mesenchymal Stem Cell-Derived Exosomes Protect Beta Cells against Hypoxia-Induced Apoptosis via MiR-21 by Alleviating ER Stress and Inhibiting P38 MAPK Phosphorylation. Stem Cell Res. Ther. 2020, 11. [CrossRef]

84. Mesples, A.; Majeed, N.; Zhang, Y.; Xiang, H. Early Immunotherapy Using Autologous Adult Stem Cells Reversed the Effect of Anti-Pancreatic Islets in Recently Diagnosed Type 1 Diabetes Mellitus: Preliminary Results. Med. Sci. Monit. 2013, 19, 852-857. [CrossRef]

85. Carlsson, P.O.; Schwarcz, E.; Korsgren, O.; le Blanc, K. Preserved $\beta$-Cell Function in Type 1 Diabetes by Mesenchymal Stromal Cells. Diabetes 2015, 64, 587-592. [CrossRef] [PubMed] 
86. Collombat, P.; Xu, X.; Ravassard, P.; Sosa-Pineda, B.; Dussaud, S.; Billestrup, N.; Madsen, O.D.; Serup, P.; Heimberg, H.; Mansouri, A. The Ectopic Expression of Pax4 in the Mouse Pancreas Converts Progenitor Cells into $\alpha$ and Subsequently $\beta$ Cells. Cell 2009, 138, 449-462. [CrossRef]

87. Thorel, F.; Népote, V.; Avril, I.; Kohno, K.; Desgraz, R.; Chera, S.; Herrera, P.L. Conversion of Adult Pancreatic $\alpha$-Cells to B-Cells after Extreme B-Cell Loss. Nature 2010, 464, 1149-1154. [CrossRef] [PubMed]

88. Abraham, E.J.; Leech, C.A.; Lin, J.C.; Zulewski, H.; Habener, J.F. Insulinotropic Hormone Glucagon-Like Peptide-1 Differentiation of Human Pancreatic Islet-Derived Progenitor Cells into Insulin-Producing Cells. Endocrinology 2002, 143. [CrossRef] [PubMed]

89. Park, M.-K.; Han, C.; Lee, K.-H.; Hong, S.-H.; Kim, H.S.; Lee, Y.-J.; Jeong, I.K.; Noh, J.-H.; Yang, T.-Y.; Lee, M.-S.; et al. Effects of Activin A on Pancreatic Ductal Cells in Streptozotocin-Induced Diabetic Rats. Transplantation 2007, 83, 925-930. [CrossRef]

90. Kim, H.S.; Hong, S.H.; Oh, S.H.; Kim, J.H.; Lee, M.S.; Lee, M.K. Activin a, Exendin-4, and Glucose Stimulate Differentiation of Human Pancreatic Ductal Cells. J. Endocrinol. 2013, 217, 241-252. [CrossRef]

91. Baeyens, L.; de Breuck, S.; Lardon, J.; Mfopou, J.K.; Rooman, I.; Bouwens, L. In Vitro Generation of Insulin-Producing Beta Cells from Adult Exocrine Pancreatic Cells. Diabetologia 2005, 48, 49-57. [CrossRef]

92. Minami, K.; Okuno, M.; Miyawaki, K.; Okumachi, A.; Ishizaki, K.; Oyama, K.; Kawaguchi, M.; Ishizuka, N.; Iwanaga, T.; Seino, S. Lineage Tracing and Characterization of Insulin-Secreting Cells Generated from Adult Pancreatic Acinar Cells. Proc. Natl. Acad. Sci. USA 2005, 102. [CrossRef]

93. Hao, E.; Tyrberg, B.; Itkin-Ansari, P.; Lakey, J.R.T.; Geron, I.; Monosov, E.Z.; Barcova, M.; Mercola, M.; Levine, F. Beta-Cell Differentiation from Nonendocrine Epithelial Cells of the Adult Human Pancreas. Nat. Med. 2006, 12, 310-316. [CrossRef]

94. Zhou, Q.; Brown, J.; Kanarek, A.; Rajagopal, J.; Melton, D.A. In Vivo Reprogramming of Adult Pancreatic Exocrine Cells to $\beta$-Cells. Nature 2008, 455, 627-632. [CrossRef]

95. Li, W.; Nakanishi, M.; Zumsteg, A.; Shear, M.; Wright, C.; Melton, D.A.; Zhou, Q. In Vivo Reprogramming of Pancreatic Acinar Cells to Three Islet Endocrine Subtypes. eLife 2014, 2014. [CrossRef]

96. Takahashi, K.; Yamanaka, S. Induction of Pluripotent Stem Cells from Mouse Embryonic and Adult Fibroblast Cultures by Defined Factors. Cell 2006, 126, 663-676. [CrossRef]

97. Okita, K.; Ichisaka, T.; Yamanaka, S. Generation of Germline-Competent Induced Pluripotent Stem Cells. Nature 2007, 448, 313-317. [CrossRef]

98. Ye, Z.; Cheng, L. Potential of Human Induced Pluripotent Stem Cells Derived from Blood and Other Postnatal Cell Types. Regen. Med. 2010, 5, 521-530. [CrossRef]

99. Damdimopoulou, P.; Rodin, S.; Stenfelt, S.; Antonsson, L.; Tryggvason, K.; Hovatta, O. Human Embryonic Stem Cells. Best Pract. Res. Clin. Obstet. Gynaecol. 2016, 31, 2-12. [CrossRef] [PubMed]

100. Liu, G.; David, B.T.; Trawczynski, M.; Fessler, R.G. Advances in Pluripotent Stem Cells: History, Mechanisms, Technologies, and Applications. Stem Cell Rev. Rep. 2020, 16, 3-32. [CrossRef]

101. Takahashi, K.; Tanabe, K.; Ohnuki, M.; Narita, M.; Ichisaka, T.; Tomoda, K.; Yamanaka, S. Induction of Pluripotent Stem Cells from Adult Human Fibroblasts by Defined Factors. Cell 2007, 131, 861-872. [CrossRef]

102. Okita, K.; Yamakawa, T.; Matsumura, Y.; Sato, Y.; Amano, N.; Watanabe, A.; Goshima, N.; Yamanaka, S. An Efficient Nonviral Method to Generate Integration-Free Human-Induced Pluripotent Stem Cells from Cord Blood and Peripheral Blood Cells. Stem Cells 2013, 31, 458-466. [CrossRef] [PubMed]

103. Xue, Y.; Cai, X.; Wang, L.; Liao, B.; Zhang, H.; Shan, Y.; Chen, Q.; Zhou, T.; Li, X.; Hou, J.; et al. Generating a Non-Integrating Human Induced Pluripotent Stem Cell Bank from Urine-Derived Cells. PLoS ONE 2013, 8. [CrossRef] [PubMed]

104. Nakagawa, M.; Koyanagi, M.; Tanabe, K.; Takahashi, K.; Ichisaka, T.; Aoi, T.; Okita, K.; Mochiduki, Y.; Takizawa, N.; Yamanaka, S. Generation of Induced Pluripotent Stem Cells without Myc from Mouse and Human Fibroblasts. Nat. Biotechnol. 2008, 26, 101-106. [CrossRef]

105. Feng, B.; Ng, J.H.; Heng, J.C.D.; Ng, H.H. Molecules That Promote or Enhance Reprogramming of Somatic Cells to Induced Pluripotent Stem Cells. Cell Stem Cell 2009, 4, 301-312. [CrossRef]

106. Yu, J.; Vodyanik, M.A.; Smuga-Otto, K.; Antosiewicz-Bourget, J.; Frane, J.L.; Tian, S.; Nie, J.; Jonsdottir, G.A.; Ruotti, V.; Stewart, R.; et al. Induced Pluripotent Stem Cell Lines Derived from Human Somatic Cells. Science 2007, 318, 1917-1920. [CrossRef]

107. Wang, J.; Rao, S.; Chu, J.; Shen, X.; Levasseur, D.N.; Theunissen, T.W.; Orkin, S.H. A Protein Interaction Network for Pluripotency of Embryonic Stem Cells. Nature 2006, 444, 364-368. [CrossRef]

108. Tsai, S.Y.; Bouwman, B.A.; Ang, Y.S.; Kim, S.J.; Lee, D.F.; Lemischka, I.R.; Rendl, M. Single Transcription Factor Reprogramming of Hair Follicle Dermal Papilla Cells to Induced Pluripotent Stem Cells. Stem Cells 2011, 29, 964-971. [CrossRef]

109. Kim, J.B.; Sebastiano, V.; Wu, G.; Araúzo-Bravo, M.J.; Sasse, P.; Gentile, L.; Ko, K.; Ruau, D.; Ehrich, M.; van den Boom, D.; et al. Oct4-Induced Pluripotency in Adult Neural Stem Cells. Cell 2009, 136, 411-419. [CrossRef] [PubMed]

110. Kim, J.B.; Greber, B.; Arazo-Bravo, M.J.; Meyer, J.; Park, K.I.; Zaehres, H.; Schöler, H.R. Direct Reprogramming of Human Neural Stem Cells by OCT4. Nature 2009, 461, 649-653. [CrossRef] [PubMed]

111. Kim, J.B.; Zaehres, H.; Wu, G.; Gentile, L.; Ko, K.; Sebastiano, V.; Araúzo-Bravo, M.J.; Ruau, D.; Han, D.W.; Zenke, M.; et al. Pluripotent Stem Cells Induced from Adult Neural Stem Cells by Reprogramming with Two Factors. Nature 2008, 454, 646-650. [CrossRef] [PubMed]

112. Wernig, M.; Meissner, A.; Cassady, J.P.; Jaenisch, R. C-Myc Is Dispensable for Direct Reprogramming of Mouse Fibroblasts. Cell Stem Cell 2008, 2, 10-12. [CrossRef] 
113. Woltjen, K.; Michael, I.P.; Mohseni, P.; Desai, R.; Mileikovsky, M.; Hämäläinen, R.; Cowling, R.; Wang, W.; Liu, P.; Gertsenstein, M.; et al. PiggyBac Transposition Reprograms Fibroblasts to Induced Pluripotent Stem Cells. Nature 2009, 458, 766-770. [CrossRef]

114. Kaji, K.; Norrby, K.; Paca, A.; Mileikovsky, M.; Mohseni, P.; Woltjen, K. Virus-Free Induction of Pluripotency and Subsequent Excision of Reprogramming Factors. Nature 2009, 458, 771-775. [CrossRef]

115. Yang, W. IPSC Reprogramming from Human Peripheral Blood Using Sendai Virus Mediated Gene Transfer. StemBook 2014. [CrossRef]

116. Fusaki, N.; Ban, H.; Nishiyama, A.; Saeki, K.; Hasegawa, M. Efficient Induction of Transgene-Free Human Pluripotent Stem Cells Using a Vector Based on Sendai Virus, an RNA Virus That Does Not Integrate into the Host Genome. Proc. Jpn. Acad. Ser. B Phys. Biol. Sci. 2009, 85, 348-362. [CrossRef] [PubMed]

117. Junying, Y.; Kejin, H.; Kim, S.O.; Shulan, T.; Stewart, R.; Slukvin, I.I.; Thomson, J.A. Human Induced Pluripotent Stem Cells Free of Vector and Transgene Sequences. Science 2009, 324, 797-801. [CrossRef]

118. Okita, K.; Matsumura, Y.; Sato, Y.; Okada, A.; Morizane, A.; Okamoto, S.; Hong, H.; Nakagawa, M.; Tanabe, K.; Tezuka, K.I.; et al. A More Efficient Method to Generate Integration-Free Human IPS Cells. Nat. Methods 2011, 8, 409-412. [CrossRef] [PubMed]

119. Warren, L.; Manos, P.D.; Ahfeldt, T.; Loh, Y.H.; Li, H.; Lau, F.; Ebina, W.; Mandal, P.K.; Smith, Z.D.; Meissner, A.; et al. Highly Efficient Reprogramming to Pluripotency and Directed Differentiation of Human Cells with Synthetic Modified MRNA. Cell Stem Cell 2010, 7, 618-630. [CrossRef]

120. Mandal, P.K.; Rossi, D.J. Reprogramming Human Fibroblasts to Pluripotency Using Modified MRNA. Nat. Protoc. 2013, 8 , 568-582. [CrossRef]

121. Sun, Y.; Liu, W.Z.; Liu, T.; Feng, X.; Yang, N.; Zhou, H.F. Signaling Pathway of MAPK/ERK in Cell Proliferation, Differentiation, Migration, Senescence and Apoptosis. J. Recept. Signal Transduct. 2015, 35, 600-604. [CrossRef]

122. Roy, S.K.; Srivastava, R.K.; Shankar, S. Inhibition of PI3K/AKT and MAPK/ERK Pathways Causes Activation of FOXO Transcription Factor, Leading to Cell Cycle Arrest and Apoptosis in Pancreatic Cancer. J. Mol. Signal. 2010, 5, 10. [CrossRef] [PubMed]

123. Wei, C.H.; Wu, G.; Cai, Q.; Gao, X.C.; Tong, F.; Zhou, R.; Zhang, R.G.; Dong, J.H.; Hu, Y.; Dong, X.R. MicroRNA-330-3p Promotes Cell Invasion and Metastasis in Non-Small Cell Lung Cancer through GRIA3 by Activating MAPK/ERK Signaling Pathway. J. Hematol. Oncol. 2017, 10. [CrossRef]

124. He, L.; Zhou, H.; Zeng, Z.; Yao, H.; Jiang, W.; Qu, H. Wnt/ $\beta$-Catenin Signaling Cascade: A Promising Target for Glioma Therapy. J. Cell. Physiol. 2019, 234, 2217-2228. [CrossRef] [PubMed]

125. Razak, S.; Afsar, T.; Ullah, A.; Almajwal, A.; Alkholief, M.; Alshamsan, A.; Jahan, S. Taxifolin, a Natural Flavonoid Interacts with Cell Cycle Regulators Causes Cell Cycle Arrest and Causes Tumor Regression by Activating Wnt/ $\beta$-Catenin Signaling Pathway 06 Biological Sciences 0601 Biochemistry and Cell Biology 11 Medical and Health Sciences 1112 Oncology and Carcinogenesis. BMC Cancer 2018, 18. [CrossRef]

126. Zhang, Z.; Li, X.; Xiao, Q.; Wang, Z. MiR-574-5p Mediates the Cell Cycle and Apoptosis in Thyroid Cancer Cells via Wnt/ $\beta$ Catenin Signaling by Repressing the Expression of Quaking Proteins. Oncol. Lett. 2018, 15, 5841-5848. [CrossRef] [PubMed]

127. Li, W.; Wei, W.; Zhu, S.; Zhu, J.; Shi, Y.; Lin, T.; Hao, E.; Hayek, A.; Deng, H.; Ding, S. Generation of Rat and Human Induced Pluripotent Stem Cells by Combining Genetic Reprogramming and Chemical Inhibitors. Cell Stem Cell 2009, 4, 16-19. [CrossRef] [PubMed]

128. Esteban, M.A.; Wang, T.; Qin, B.; Yang, J.; Qin, D.; Cai, J.; Li, W.; Weng, Z.; Chen, J.; Ni, S.; et al. Vitamin C Enhances the Generation of Mouse and Human Induced Pluripotent Stem Cells. Cell Stem Cell 2010, 6, 71-79. [CrossRef] [PubMed]

129. Kang, S.J.; Park, Y.I.; So, B.; Kang, H.G. Sodium Butyrate Efficiently Converts Fully Reprogrammed Induced Pluripotent Stem Cells from Mouse Partially Reprogrammed Cells. Cell. Reprogram. 2014, 16, 345-354. [CrossRef]

130. Huangfu, D.; Maehr, R.; Guo, W.; Eijkelenboom, A.; Snitow, M.; Chen, A.E.; Melton, D.A. Induction of Pluripotent Stem Cells by Defined Factors Is Greatly Improved by Small-Molecule Compounds. Nat. Biotechnol. 2008, 26, 795-797. [CrossRef]

131. Hou, P.; Li, Y.; Zhang, X.; Liu, C.; Guan, J.; Li, H.; Zhao, T.; Ye, J.; Yang, W.; Liu, K.; et al. Pluripotent Stem Cells Induced from Mouse Somatic Cells by Small-Molecule Compounds. Science 2013, 341, 651-654. [CrossRef]

132. Zhao, Y.; Zhao, T.; Guan, J.; Zhang, X.; Fu, Y.; Ye, J.; Zhu, J.; Meng, G.; Ge, J.; Yang, S.; et al. A XEN-like State Bridges Somatic Cells to Pluripotency during Chemical Reprogramming. Cell 2015, 163, 1678-1691. [CrossRef]

133. Pagliuca, F.W.; Millman, J.R.; Gürtler, M.; Segel, M.; van Dervort, A.; Ryu, J.H.; Peterson, Q.P.; Greiner, D.; Melton, D.A. Generation of Functional Human Pancreatic $\beta$ Cells In Vitro. Cell 2014, 159, 428-439. [CrossRef]

134. Russ, H.A.; Parent, A.V.; Ringler, J.J.; Hennings, T.G.; Nair, G.G.; Shveygert, M.; Guo, T.; Puri, S.; Haataja, L.; Cirulli, V.; et al. Controlled Induction of Human Pancreatic Progenitors Produces Functional Beta-like Cells In Vitro. EMBO J. 2015, 34, 1759-1772. [CrossRef]

135. Yoshioka, M.; Kayo, T.; Ikeda, T.; Koizumi, A. A Novel Locus, Mody4, Distal to D7Mit189 on Chromosome 7 Determines Early-Onset NIDDM in Nonobese C57BL/ 6 (Akita) Mutant Mice. Diabetes 1997, 46, 887-894. [CrossRef] [PubMed]

136. Ma, X.; Zhu, S. Chemical Strategies for Pancreatic $\beta$ Cell Differentiation, Reprogramming, and Regeneration. Acta Biochim. Biophys. Sin. 2017, 49, 298-301. [CrossRef]

137. Yabe, S.G.; Fukuda, S.; Takeda, F.; Nashiro, K.; Shimoda, M.; Okochi, H. Efficient Generation of Functional Pancreatic $\beta$-Cells from Human Induced Pluripotent Stem Cells. J. Diabetes 2017, 9, 168-179. [CrossRef] 
138. Memon, B.; Karam, M.; Al-Khawaga, S.; Abdelalim, E.M. Enhanced Differentiation of Human Pluripotent Stem Cells into Pancreatic Progenitors Co-Expressing PDX1 and NKX6.1. Stem Cell Res. Ther. 2018, 9, 1-15. [CrossRef]

139. Shahjalal, H.M.; Shiraki, N.; Sakano, D.; Kikawa, K.; Ogaki, S.; Baba, H.; Kume, K.; Kume, S. Generation of Insulin-Producing $\beta$-like Cells from Human IPS Cells in a Defined and Completely Xeno-Free Culture System. J. Mol. Cell Biol. 2014, 6, 394-408. [CrossRef] [PubMed]

140. Zhang, D.; Jiang, W.; Liu, M.; Sui, X.; Yin, X.; Chen, S.; Shi, Y.; Deng, H. Highly Efficient Differentiation of Human ES Cells and IPS Cells into Mature Pancreatic Insulin-Producing Cells. Cell Res. 2009, 19, 429-438. [CrossRef] [PubMed]

141. Rezania, A.; Bruin, J.E.; Arora, P.; Rubin, A.; Batushansky, I.; Asadi, A.; O’Dwyer, S.; Quiskamp, N.; Mojibian, M.; Albrecht, T.; et al. Reversal of Diabetes with Insulin-Producing Cells Derived In Vitro from Human Pluripotent Stem Cells. Nat. Biotechnol. 2014, 32, 1121-1133. [CrossRef]

142. Nair, G.G.; Liu, J.S.; Russ, H.A.; Tran, S.; Saxton, M.S.; Chen, R.; Juang, C.; Li, M.I.; Nguyen, V.Q.; Giacometti, S.; et al. Recapitulating Endocrine Cell Clustering in Culture Promotes Maturation of Human Stem-Cell-Derived $\beta$ Cells. Nat. Cell Biol. 2019, 21, 263-274. [CrossRef]

143. Li, X.; Yang, K.Y.; Chan, V.W.; Leung, K.T.; Zhang, X.B.; Wong, A.S.; Chong, C.C.N.; Wang, C.C.; Ku, M.; Lui, K.O. Single-Cell RNA-Seq Reveals That CD9 Is a Negative Marker of Glucose-Responsive Pancreatic $\beta$-like Cells Derived from Human Pluripotent Stem Cells. Stem Cell Rep. 2020, 15, 1111-1126. [CrossRef]

144. Yoshihara, E.; O'Connor, C.; Gasser, E.; Wei, Z.; Oh, T.G.; Tseng, T.W.; Wang, D.; Cayabyab, F.; Dai, Y.; Yu, R.T.; et al. ImmuneEvasive Human Islet-like Organoids Ameliorate Diabetes. Nature 2020, 586, 606-611. [CrossRef]

145. Petersen, M.B.K.; Azad, A.; Ingvorsen, C.; Hess, K.; Hansson, M.; Grapin-Botton, A.; Honoré, C. Single-Cell Gene Expression Analysis of a Human ESC Model of Pancreatic Endocrine Development Reveals Different Paths to $\beta$-Cell Differentiation. Stem Cell Rep. 2017, 9, 1246-1261. [CrossRef]

146. Wang, Q.; Donelan, W.; Ye, H.; Jin, Y.; Lin, Y.; Wu, X.; Wang, Y.; Xi, Y. Real-Time Observation of Pancreatic Beta Cell Differentiation from Human Induced Pluripotent Stem Cells. Am. J. Transl. Res. 2019, 11, 3490-3504.

147. Velazco-Cruz, L.; Song, J.; Maxwell, K.G.; Goedegebuure, M.M.; Augsornworawat, P.; Hogrebe, N.J.; Millman, J.R. Acquisition of Dynamic Function in Human Stem Cell-Derived $\beta$ Cells. Stem Cell Rep. 2019, 12, 351-365. [CrossRef]

148. Sharon, N.; Vanderhooft, J.; Straubhaar, J.; Mueller, J.; Chawla, R.; Zhou, Q.; Engquist, E.N.; Trapnell, C.; Gifford, D.K.; Melton, D.A. Wnt Signaling Separates the Progenitor and Endocrine Compartments during Pancreas Development. Cell Rep. 2019, 27, 2281-2291.e5. [CrossRef]

149. D’Amour, K.A.; Bang, A.G.; Eliazer, S.; Kelly, O.G.; Agulnick, A.D.; Smart, N.G.; Moorman, M.A.; Kroon, E.; Carpenter, M.K.; Baetge, E.E. Production of Pancreatic Hormone-Expressing Endocrine Cells from Human Embryonic Stem Cells. Nat. Biotechnol. 2006, 24, 1392-1401. [CrossRef]

150. Jiang, J.; Au, M.; Lu, K.; Eshpeter, A.; Korbutt, G.; Fisk, G.; Majumdar, A.S. Generation of Insulin-Producing Islet-Like Clusters from Human Embryonic Stem Cells. Stem Cells 2007, 25, 1940-1953. [CrossRef]

151. Bruin, J.E.; Erener, S.; Vela, J.; Hu, X.; Johnson, J.D.; Kurata, H.T.; Lynn, F.C.; Piret, J.M.; Asadi, A.; Rezania, A.; et al. Characterization of Polyhormonal Insulin-Producing Cells Derived In Vitro from Human Embryonic Stem Cells. Stem Cell Res. 2014, 12, 194-208. [CrossRef] [PubMed]

152. Jiang, W.; Shi, Y.; Zhao, D.; Chen, S.; Yong, J.; Zhang, J.; Qing, T.; Sun, X.; Zhang, P.; Ding, M.; et al. In Vitro Derivation of Functional Insulin-Producing Cells from Human Embryonic Stem Cells. Cell Res. 2007, 17, 333-344. [CrossRef] [PubMed]

153. Phillips, B.W.; Hentze, H.; Rust, W.L.; Chen, Q.P.; Chipperfield, H.; Tan, E.K.; Abraham, S.; Sadasivam, A.; Poh, L.S.; Siew, T.W.; et al. Directed Differentiation of Human Embryonic Stem Cells into the Pancreatic Endocrine Lineage. Stem Cells Dev. 2007, 16, 561-578. [CrossRef] [PubMed]

154. Kroon, E.; Martinson, L.A.; Kadoya, K.; Bang, A.G.; Kelly, O.G.; Eliazer, S.; Young, H.; Richardson, M.; Smart, N.G.; Cunningham, J.; et al. Pancreatic Endoderm Derived from Human Embryonic Stem Cells Generates Glucose-Responsive Insulin-Secreting Cells In Vivo. Nat. Biotechnol. 2008, 26, 443-452. [CrossRef] [PubMed]

155. Rezania, A.; Bruin, J.E.; Riedel, M.J.; Mojibian, M.; Asadi, A.; Xu, J.; Gauvin, R.; Narayan, K.; Karanu, F.; O’Neil, J.J.; et al. Maturation of Human Embryonic Stem Cell-Derived Pancreatic Progenitors into Functional Islets Capable of Treating PreExisting Diabetes in Mice. Diabetes 2012, 61, 2016-2029. [CrossRef]

156. Bruin, J.E.; Asadi, A.; Fox, J.K.; Erener, S.; Rezania, A.; Kieffer, T.J. Accelerated Maturation of Human Stem Cell-Derived Pancreatic Progenitor Cells into Insulin-Secreting Cells in Immunodeficient Rats Relative to Mice. Stem Cell Rep. 2015, 5, 1081-1096. [CrossRef] [PubMed]

157. Schulz, T.C. Enabling Technologies for Cell-Based Clinical Translation Concise Review: Manufacturing of Pancreatic Endoderm Cells for Clinical Trials in Type 1 Diabetes. Stem Cells Transl. Med. 2015, 4, 927-931. [CrossRef] [PubMed]

158. Shapiro, A.J.; Thompson, D.; Donner, T.W.; Bellin, M.D.; Hsueh, W. Insulin Expression and Glucose-Responsive Circulating C-Peptide in Type 1 Diabetes Patients Implanted Subcutaneously with Pluripotent Stem Cell-Derived Pancreatic Endoderm Cells in a Macro-Device. Lancet 2019. [CrossRef]

159. Wang, H.; Brun, T.; Kataoka, K.; Sharma, A.J.; Wollheim, C.B. MAFA Controls Genes Implicated in Insulin Biosynthesis and Secretion. Diabetologia 2007, 50, 348-358. [CrossRef] [PubMed]

160. Jeon, J.; Correa-Medina, M.; Ricordi, C.; Edlund, H.; Diez, J.A. Endocrine Cell Clustering during Human Pancreas Development. J. Histochem. Cytochem. 2009, 57, 811-824. [CrossRef] [PubMed] 
161. Stock, A.A.; Manzoli, V.; de Toni, T.; Abreu, M.M.; Poh, Y.C.; Ye, L.; Roose, A.; Pagliuca, F.W.; Thanos, C.; Ricordi, C.; et al. Conformal Coating of Stem Cell-Derived Islets for $\beta$ Cell Replacement in Type 1 Diabetes. Stem Cell Rep. 2020, 14, 91-104. [CrossRef]

162. Vegas, A.J.; Veiseh, O.; Gürtler, M.; Millman, J.R.; Pagliuca, F.W.; Bader, A.R.; Doloff, J.C.; Li, J.; Chen, M.; Olejnik, K.; et al. Long-Term Glycemic Control Using Polymer-Encapsulated Human Stem Cell-Derived Beta Cells in Immune-Competent Mice. Nat. Med. 2016, 22, 306-311. [CrossRef]

163. de Klerk, E.; Hebrok, M. Stem Cell-Based Clinical Trials for Diabetes Mellitus. Front. Endocrinol. 2021, 12. [CrossRef]

164. Brissova, M.; Haliyur, R.; Saunders, D.; Shrestha, S.; Dai, C.; Blodgett, D.M.; Bottino, R.; Campbell-Thompson, M.; Aramandla, R.; Poffenberger, G.; et al. $\alpha$ Cell Function and Gene Expression Are Compromised in Type 1 Diabetes. Cell Rep. 2018, 22, 2667-2676. [CrossRef]

165. Siafarikas, A.; Johnston, R.J.; Bulsara, M.K.; O’Leary, P.; Jones, T.W.; Davis, E.A. Early Loss of the Glucagon Response to Hypoglycemia in Adolescents with Type 1 Diabetes. Diabetes Care 2012, 35, 1757-1762. [CrossRef]

166. Rezania, A.; Riedel, M.J.; Wideman, R.D.; Karanu, F.; Ao, Z.; Warnock, G.L.; Kieffer, T.J. Production of Functional GlucagonSecreting $\alpha$-Cells from Human Embryonic Stem Cells. Diabetes 2011, 60, 239-247. [CrossRef] [PubMed]

167. Peterson, Q.P.; Veres, A.; Chen, L.; Slama, M.Q.; Kenty, J.H.R.; Hassoun, S.; Brown, M.R.; Dou, H.; Duffy, C.D.; Zhou, Q.; et al. A Method for the Generation of Human Stem Cell-Derived Alpha Cells. Nat. Commun. 2020, 11, 1-14. [CrossRef] [PubMed]

168. Russell, M.A.; Redick, S.D.; Blodgett, D.M.; Richardson, S.J.; Leete, P.; Krogvold, L.; Dahl-Jørgensen, K.; Bottino, R.; Brissova, M.; Spaeth, J.M.; et al. HLA Class II Antigen Processing and Presentation Pathway Components Demonstrated by Transcriptome and Protein Analyses of Islet $\beta$-Cells from Donors with Type 1 Diabetes. Diabetes 2019, 68, 988-1001. [CrossRef]

169. Pugliese, A. Autoreactive T Cells in Type 1 Diabetes. J. Clin. Investig. 2017, 127, 2881-2891. [CrossRef]

170. Choo, S.Y. The HLA System: Genetics, Immunology, Clinical Testing, and Clinical Implications. Yonsei Med. J. 2007, 48, 11. [CrossRef] [PubMed]

171. Matsumura, M.; Fremont, D.H.; Peterson, P.A.; Wilson, I.A. Emerging Principles for the Recognition of Peptide Antigens by MHC Class I Molecules. Science 1992, 257, 927-934. [CrossRef] [PubMed]

172. Shiina, T.; Inoko, H.; Kulski, J.K. An Update of the HLA Genomic Region, Locus Information and Disease Associations: 2004. Tissue Antigens 2004, 64, 631-649. [CrossRef]

173. Hu, X.; Deutsch, A.J.; Lenz, T.L.; Onengut-Gumuscu, S.; Han, B.; Chen, W.M.; Howson, J.M.M.; Todd, J.A.; De Bakker, P.I.W.; Rich, S.S.; et al. Additive and Interaction Effects at Three Amino Acid Positions in HLA-DQ and HLA-DR Molecules Drive Type 1 Diabetes Risk. Nat. Genet. 2015, 47, 898-905. [CrossRef]

174. Kumar, V.; Abbas, A.K.; Fausto, N.; Mitchell, R.S. Robbins Basic Pathology, 8th ed.; Saunders: Philadelphia, PA, USA, 2010. Available online: https:/ / medbook.com.pl/ksiazka/pokaz/id/30048/tytul/robbins-basic-pathology-kumar-abbas-fausto-mitchellsaunders (accessed on 17 August 2020).

175. Margaritte-Jeannin, P.; Babron, M.C.; Bourgey, M.; Louka, A.S.; Clot, F.; Percopo, S.; Coto, I.; Hugot, J.P.; Ascher, H.; Sollid, L.M.; et al. HLA-DQ Relative Risks for Coeliac Disease in European Populations: A Study of the European Genetics Cluster on Coeliac Disease. Tissue Antigens 2004, 63, 562-567. [CrossRef]

176. Wicker, L.S.; Leiter, E.H.; Todd, J.A.; Renjilian, R.J.; Peterson, E.; Fischer, P.A.; Podolin, P.L.; Zijlstra, M.; Jaenisch, R.; Peterson, L.B. B2-Microglobulin-Deficient NOD Mice Do Not Develop Insulitis or Diabetes. Diabetes 1994, 43, 500-504. [CrossRef] [PubMed]

177. Serreze, D.V.; Leiter, E.H.; Christianson, G.J.; Greiner, D.; Roopenian, D.C. Major Histocompatibility Complex Class I-Deficient N0D-E2/n. Diabetes 1994, 43, 505-509. [CrossRef] [PubMed]

178. Challa-Malladi, M.; Lieu, Y.K.; Califano, O.; Holmes, A.B.; Bhagat, G.; Murty, V.V.; Dominguez-Sola, D.; Pasqualucci, L.; DallaFavera, R. Combined Genetic Inactivation of B2-Microglobulin and CD58 Reveals Frequent Escape from Immune Recognition in Diffuse Large B Cell Lymphoma. Cancer Cell 2011, 20, 728-740. [CrossRef] [PubMed]

179. Nedelkovska, H.; Edholm, E.S.; Haynes, N.; Robert, J. Effective RNAi-Mediated B2-Microglobulin Loss of Function by Transgenesis in Xenopus laevis. Biol. Open 2013, 2, 335-342. [CrossRef] [PubMed]

180. Mandal, P.K.; Ferreira, L.M.R.; Collins, R.; Meissner, T.B.; Boutwell, C.L.; Friesen, M.; Vrbanac, V.; Garrison, B.S.; Stortchevoi, A.; Bryder, D.; et al. Efficient Ablation of Genes in Human Hematopoietic Stem and Effector Cells Using CRISPR/Cas9. Cell Stem Cell 2014, 15, 643-652. [CrossRef] [PubMed]

181. Wang, D.; Quan, Y.; Qing, Y.; Morales, J.E.; Wetsel, R.A. Targeted Disruption of the B2-Microglobulin Gene Minimizes the Immunogenicity of Human Embryonic Stem Cells. Stem Cells Transl. Med. 2014, 4, 1-10.

182. Chen, H.; Li, Y.; Lin, X.; Cui, D.; Cui, C.; Li, H.; Xiao, L. Functional Disruption of Human Leukocyte Antigen II in Human Embryonic Stem Cell. Biol. Res. 2015, 48, 1-9. [CrossRef]

183. Sade-Feldman, M.; Jiao, Y.J.; Chen, J.H.; Rooney, M.S.; Barzily-Rokni, M.; Eliane, J.P.; Bjorgaard, S.L.; Hammond, M.R.; Vitzthum, H.; Blackmon, S.M.; et al. Resistance to Checkpoint Blockade Therapy through Inactivation of Antigen Presentation. Nat. Commun. 2017, 8. [CrossRef]

184. Mattapally, S.; Pawlik, K.M.; Fast, V.G.; Zumaquero, E.; Lund, F.E.; Randall, T.D.; Townes, T.M.; Zhang, J. Human Leukocyte Antigen Class I and II Knockout Human Induced Pluripotent Stem Cell-Derived Cells: Universal Donor for Cell Therapy. J. Am. Heart Assoc. 2018, 7, 1-13. [CrossRef]

185. Zijlstra, M.; Bix, M.; Simister, N.E.; Loring, J.M.; Raulet, D.H.; Jaenisch, R. B2-Microglobulin Deficient Mice Lack CD4 ${ }^{-} 8^{+}$Cytolytic T Cells. Nature 1990, 344, 742-746. [CrossRef] 
186. Bjorkman, P.J.; Saper, M.A.; Samraoui, B.; Bennett, W.S.; Strominger, J.L.; Wiley, D.C. Structure of the Human Class I Histocompatibility Antigen, HLA-A2. Nature 1987, 329, 506-512. [CrossRef]

187. Chang, C.H.; Fontes, J.D.; Peterlin, M.; Flavell, R.A. Class II Transactivator (CIITA) Is Sufficient for the Inducible Expression of Major Histocompatibility Complex Class II Genes. J. Exp. Med. 1994, 180, 1367-1374. [CrossRef]

188. Chang, C.H.; Flavell, R.A. Class II Transactivator Regulates the Expression of Multiple Genes Involved in Antigen Presentation. J. Exp. Med. 1995, 181, 765-767. [CrossRef] [PubMed]

189. Buch, T.; Polic, B.; Clausen, B.E.; Weiss, S.; Akilli-Ozturk, O.; Chang, C.-H.; Flavell, R.; Schulz, A.; Jonjic, S.; Waisman, A.; et al. MHC Class II Expression through a Hitherto Unknown Pathway Supports T Helper Cell-Dependent Immune Responses: Implications for MHC Class II Deficiency. Blood 2006, 107, 1434-1444. [CrossRef] [PubMed]

190. Hong, C.H.; Sohn, H.J.; Lee, H.J.; Cho, H.I.; Kim, T.G. Antigen Presentation by Individually Transferred HLA Class i Genes in HLA-A, HLA-B, HLA-C Null Human Cell Line Generated Using the Multiplex CRISPR-Cas9 System. J. Immunother. 2017, 40, 201-210. [CrossRef] [PubMed]

191. Jang, Y.; Choi, J.; Park, N.; Kang, J.; Kim, M.; Kim, Y.; Ju, J.H. Development of Immunocompatible Pluripotent Stem Cells via CRISPR-Based Human Leukocyte Antigen Engineering. Exp. Mol. Med. 2019, 51. [CrossRef] [PubMed]

192. Gornalusse, G.G.; Hirata, R.K.; Funk, S.E.; Riolobos, L.; Lopes, V.S.; Manske, G.; Prunkard, D.; Colunga, A.G.; Hanafi, L.A.; Clegg, D.O.; et al. HLA-E-Expressing Pluripotent Stem Cells Escape Allogeneic Responses and Lysis by NK Cells. Nat. Biotechnol. 2017, 35, 765-772. [CrossRef]

193. Deuse, T.; Hu, X.; Gravina, A.; Wang, D.; Tediashvili, G.; De, C.; Thayer, W.O.; Wahl, A.; Garcia, J.V.; Reichenspurner, H.; et al. Hypoimmunogenic Derivatives of Induced Pluripotent Stem Cells Evade Immune Rejection in Fully Immunocompetent Allogeneic Recipients. Nat. Biotechnol. 2019, 37, 252-258. [CrossRef]

194. Han, X.; Wang, M.; Duan, S.; Franco, P.J.; Kenty, J.H.R.; Hedrick, P.; Xia, Y.; Allen, A.; Ferreira, L.M.R.; Strominger, J.L.; et al. Generation of Hypoimmunogenic Human Pluripotent Stem Cells. Proc. Natl. Acad. Sci. USA 2019, 116, 10441-10446. [CrossRef] [PubMed]

195. Xu, H.; Wang, B.; Ono, M.; Kagita, A.; Fujii, K.; Sasakawa, N.; Ueda, T.; Gee, P.; Nishikawa, M.; Nomura, M.; et al. Targeted Disruption of HLA Genes via CRISPR-Cas9 Generates IPSCs with Enhanced Immune Compatibility. Cell Stem Cell 2019, 24, 566-578.e7. [CrossRef]

196. Shi, L.; Li, W.; Liu, Y.; Chen, Z.; Hui, Y.; Hao, P.; Xu, X.; Zhang, S.; Feng, H.; Zhang, B.; et al. Generation of Hypoimmunogenic Human Pluripotent Stem Cells via Expression of Membrane-Bound and Secreted B2m-HLA-G Fusion Proteins. Stem Cells 2020, 38, 1423-1437. [CrossRef]

197. Lister, R.; Pelizzola, M.; Kida, Y.S.; Hawkins, R.D.; Nery, J.R.; Hon, G.; Antosiewicz-Bourget, J.; Ogmalley, R.; Castanon, R.; Klugman, S.; et al. Hotspots of Aberrant Epigenomic Reprogramming in Human Induced Pluripotent Stem Cells. Nature 2011, 471, 68-73. [CrossRef]

198. Gore, A.; Li, Z.; Fung, H.L.; Young, J.E.; Agarwal, S.; Antosiewicz-Bourget, J.; Canto, I.; Giorgetti, A.; Israel, M.A.; Kiskinis, E.; et al. Somatic Coding Mutations in Human Induced Pluripotent Stem Cells. Nature 2011, 471, 63-67. [CrossRef]

199. Miura, K.; Okada, Y.; Aoi, T.; Okada, A.; Takahashi, K.; Okita, K.; Nakagawa, M.; Koyanagi, M.; Tanabe, K.; Ohnuki, M.; et al. Variation in the Safety of Induced Pluripotent Stem Cell Lines. Nat. Biotechnol. 2009, 27, 743-745. [CrossRef] [PubMed]

200. Okano, H.; Nakamura, M.; Yoshida, K.; Okada, Y.; Tsuji, O.; Nori, S.; Ikeda, E.; Yamanaka, S.; Miura, K. Steps toward Safe Cell Therapy Using Induced Pluripotent Stem Cells. Circ. Res. 2013, 112, 523-533. [CrossRef] [PubMed]

201. Introna, M.; Barbui, A.M.; Bambacioni, F.; Casati, C.; Gaipa, G.; Borleri, G.; Bernasconi, S.; Barbui, T.; Golay, J.; Biondi, A.; et al. Genetic Modification of Human T Cells with CD20: A Strategy to Purify and Lyse Transduced Cells with Anti-CD20 Antibodies. Hum. Gene Ther. 2000, 11, 611-620. [CrossRef] [PubMed]

202. Poulsen, T.T.; Pedersen, N.; Juel, H.; Poulsen, H.S. A Chimeric Fusion of the HASH1 and EZH2 Promoters Mediates High and Specific Reporter and Suicide Gene Expression and Cytotoxicity in Small Cell Lung Cancer Cells. Cancer Gene Ther. 2008, 15, 563-575. [CrossRef] [PubMed]

203. Fan, L.; Freeman, K.W.; Khan, T.; Pham, E.; Spencer, D.M. Improved Artificial Death Switches Based on Caspases and FADD. Hum. Gene Ther. 1999, 10, 2273-2285. [CrossRef] [PubMed]

204. Clackson, T.; Yang, W.; Rozamus, L.W.; Hatada, M.; Amara, J.F.; Rollins, C.T.; Stevenson, L.F.; Magari, S.R.; Wood, S.A.; Courage, N.L.; et al. Redesigning an FKBP-Ligand Interface to Generate Chemical Dimerizers with Novel Specificity. Proc. Natl. Acad. Sci. USA 1998, 95, 10437-10442. [CrossRef] [PubMed]

205. Zhou, X.; Naik, S.; Dakhova, O.; Dotti, G.; Heslop, H.E.; Brenner, M.K. Serial Activation of the Inducible Caspase 9 Safety Switch after Human Stem Cell Transplantation. Mol. Ther. 2016, 24, 823-831. [CrossRef]

206. Di Stasi, A.; Tey, S.K.; Dotti, G.; Fujita, Y.; Kennedy-Nasser, A.; Martinez, C.; Straathof, K.; Liu, E.; Durett, A.G.; Grilley, B.; et al. Inducible Apoptosis as a Safety Switch for Adoptive Cell Therapy. N. Engl. J. Med. 2011, 365, 1673-1683. [CrossRef]

207. Straathof, K.C.; Pulè, M.A.; Yotnda, P.; Dotti, G.; Vanin, E.F.; Brenner, M.K.; Heslop, H.E.; Spencer, D.M.; Rooney, C.M. An Inducible Caspase 9 Safety Switch for T-Cell Therapy. Blood 2005, 105, 4247-4254. [CrossRef]

208. Shi, Z.D.; Tchao, J.; Wu, L.; Carman, A.J. Precision Installation of a Highly Efficient Suicide Gene Safety Switch in Human Induced Pluripotent Stem Cells. Stem Cells Transl. Med. 2020, 9. [CrossRef] [PubMed]

209. González, F.; Zhu, Z.; Shi, Z.D.; Lelli, K.; Verma, N.; Li, Q.V.; Huangfu, D. An ICRISPR Platform for Rapid, Multiplexable, and Inducible Genome Editing in Human Pluripotent Stem Cells. Cell Stem Cell 2014, 15, 215-226. [CrossRef] 
210. DeKelver, R.C.; Choi, V.M.; Moehle, E.A.; Paschon, D.E.; Hockemeyer, D.; Meijsing, S.H.; Sancak, Y.; Cui, X.; Steine, E.J.; Miller, J.C.; et al. Functional Genomics, Proteomics, and Regulatory DNA Analysis in Isogenic Settings Using Zinc Finger Nuclease-Driven Transgenesis into a Safe Harbor Locus in the Human Genome. Genome Res. 2010, 20, 1133-1142. [CrossRef] [PubMed]

211. Sadelain, M.; Papapetrou, E.P.; Bushman, F.D. Safe Harbours for the Integration of New DNA in the Human Genome. Nat. Rev. Cancer 2012, 12, 51-58. [CrossRef] [PubMed]

212. Moede, T.; Leibiger, I.B.; Berggren, P.O. Alpha Cell Regulation of Beta Cell Function. Diabetologia 2020, 63, 2064-2075. [CrossRef]

213. Adams, M.T.; Gilbert, J.M.; Hinojosa Paiz, J.; Bowman, F.M.; Blum, B. Endocrine Cell Type Sorting and Mature Architecture in the Islets of Langerhans Require Expression of Roundabout Receptors in $\beta$ Cells. Sci. Rep. 2018, 8. [CrossRef] [PubMed]

214. Kitsou-Mylona, I.; Burns, C.J.; Squires, P.E.; Persaud, S.J.; Jones, P.M. A Role for the Extracellular Calcium-Sensing Receptor in Cell-Cell Communication in Pancreatic Islets of Langerhans. Cell. Physiol. Biochem. 2008, 22, 557-566. [CrossRef]

215. Aamodt, K.I.; Powers, A.C. Signals in the Pancreatic Islet Microenvironment Influence $\beta$-Cell Proliferation. Diabetes Obes. Metab. 2017, 19, 124-136. [CrossRef]

216. Abdulreda, M.H.; Rodriguez-Diaz, R.; Cabrera, O.; Caicedo, A.; Berggren, P.O. The different faces of the pancreatic islet. In Advances in Experimental Medicine and Biology; Springer: New York, NY, USA, 2016; Volume 938, pp. 11-24.

217. Röder, P.V.; Wu, B.; Liu, Y.; Han, W. Pancreatic Regulation of Glucose Homeostasis. Exp. Mol. Med. 2016, 48, e219. [CrossRef] [PubMed]

218. Hoang Do, O.; Thorn, P. Insulin Secretion from Beta Cells within Intact Islets: Location Matters. Clin. Exp. Pharmacol. Physiol. 2015, 42, 406-414. [CrossRef] [PubMed]

219. Jun, Y.; Lee, J.S.; Choi, S.; Yang, J.H.; Sander, M.; Chung, S.; Lee, S.H. In Vivo-Mimicking Microfluidic Perfusion Culture of Pancreatic Islet Spheroids. Sci. Adv. 2019, 5, eaax4520. [CrossRef] [PubMed]

220. Napierala, H.; Hillebrandt, K.H.; Haep, N.; Tang, P.; Tintemann, M.; Gassner, J.; Noesser, M.; Everwien, H.; Seiffert, N.; Kluge, M.; et al. Engineering an Endocrine Neo-Pancreas by Repopulation of a Decellularized Rat Pancreas with Islets of Langerhans. Sci. Rep. 2017, 7, 1-12. [CrossRef]

221. Everwien, H.; Keshi, E.; Hillebrandt, K.H.; Ludwig, B.; Weinhart, M.; Tang, P.; Beierle, A.S.; Napierala, H.; Gassner, J.M.; Seiffert, N.; et al. Engineering an Endothelialized, Endocrine Neo-Pancreas: Evaluation of Islet Functionality in an Ex Vivo Model. Acta Biomater. 2020, 117. [CrossRef]

222. Ribeiro, D.; Kvist, A.J.; Wittung-Stafshede, P.; Hicks, R.; Forslöw, A. 3D-Models of Insulin-Producing $\beta$-Cells: From Primary Islet Cells to Stem Cell-Derived Islets. Stem Cell Rev. Rep. 2018, 14, 177-188. [CrossRef]

223. Caicedo, A. Paracrine and Autocrine Interactions in the Human Islet: More than Meets the Eye. Semin. Cell Dev. Biol. 2013, 24, 11-21. [CrossRef]

224. Eberhard, D.; Kragl, M.; Lammert, E. "Giving and Taking": Endothelial and $\beta$-Cells in the Islets of Langerhans. Trends Endocrinol. Metab. 2010, 21, 457-463. [CrossRef]

225. Tomei, A.A.; Manzoli, V.; Fraker, C.A.; Giraldo, J.; Velluto, D.; Najjar, M.; Pileggi, A.; Molano, R.D.; Ricordi, C.; Stabler, C.L.; et al. Device Design and Materials Optimization of Conformal Coating for Islets of Langerhans. Proc. Natl. Acad. Sci. USA 2014, 111, 10514-10519. [CrossRef]

226. Qi, M.; Strand, B.L.; Mørch, Y.; Lacík, I.; Wang, Y.; Salehi, P.; Barbaro, B.; Gangemi, A.; Kuechle, J.; Romagnoli, T.; et al. Encapsulation of Human Islets in Novel Inhomogeneous Alginate-Ca ${ }^{2+} / \mathrm{Ba}^{2+}$ Microbeads: In Vitro and In Vivo Function. Artif. Cells Blood Substit. Biotechnol. 2008, 36, 403-420. [CrossRef]

227. Strand, B.L.; Gåserød, O.; Kulseng, B.; Espevik, T.; Skjåk-Bræk, G. Alginate-Polylysine-Alginate Microcapsules: Effect of Size Reduction on Capsule Properties. J. Microencapsul. 2002, 19, 615-630. [CrossRef] [PubMed]

228. Buchwald, P.; Tamayo-Garcia, A.; Manzoli, V.; Tomei, A.A.; Stabler, C.L. Glucose-Stimulated Insulin Release: Parallel Perifusion Studies of Free and Hydrogel Encapsulated Human Pancreatic Islets. Biotechnol. Bioeng. 2018, 115, 232-245. [CrossRef] [PubMed]

229. Novosel, E.C.; Kleinhans, C.; Kluger, P.J. Vascularization Is the Key Challenge in Tissue Engineering. Adv. Drug Deliv. Rev. 2011, 63, 300-311. [CrossRef] [PubMed]

230. Shor, L.; Güçeri, S.; Chang, R.; Gordon, J.; Kang, Q.; Hartsock, L.; An, Y.; Sun, W. Precision Extruding Deposition (PED) Fabrication of Polycaprolactone (PCL) Scaffolds for Bone Tissue Engineering. Biofabrication 2009, 1. [CrossRef] [PubMed]

231. Xu, T.; Zhao, W.; Zhu, J.M.; Albanna, M.Z.; Yoo, J.J.; Atala, A. Complex Heterogeneous Tissue Constructs Containing Multiple Cell Types Prepared by Inkjet Printing Technology. Biomaterials 2013, 34, 130-139. [CrossRef]

232. Barron, J.A.; Wu, P.; Ladouceur, H.D.; Ringeisen, B.R. Biological Laser Printing: A Novel Technique for Creating Heterogeneous 3-Dimensional Cell Patterns. Biomed. Microdevices 2004, 6, 139-147. [CrossRef]

233. Wang, Z.; Tian, Z.; Jin, X.; Holzman, J.F.; Menard, F.; Kim, K. Visible Light-Based Stereolithography Bioprinting of Cell-Adhesive Gelatin Hydrogels. In Proceedings of the 39th Annual International Conference of the IEEE Engineering in Medicine and Biology Society (EMBC), Jeju, Korea, 11-15 July 2017; pp. 1599-1602. [CrossRef]

234. Klak, M.; Bryniarski, T.; Kowalska, P.; Gomolka, M.; Tymicki, G.; Kosowska, K.; Cywoniuk, P.; Dobrzanski, T.; Turowski, P.; Wszola, M. Novel Strategies in Artificial Organ Development: What Is the Future of Medicine? Micromachines 2020, 11, 646. [CrossRef] [PubMed]

235. Marchioli, G.; van Gurp, L.; van Krieken, P.P.; Stamatialis, D.; Engelse, M.; van Blitterswijk, C.A.; Karperien, M.B.J.; de Koning, E.; Alblas, J.; Moroni, L.; et al. Fabrication of Three-Dimensional Bioplotted Hydrogel Scaffolds for Islets of Langerhans Transplantation. Biofabrication 2015, 7, 25009. [CrossRef] [PubMed] 
236. Duin, S.; Schütz, K.; Ahlfeld, T.; Lehmann, S.; Lode, A.; Ludwig, B.; Gelinsky, M. 3D Bioprinting of Functional Islets of Langerhans in an Alginate/Methylcellulose Hydrogel Blend. Adv. Healthc. Mater. 2019, 8, 1-14. [CrossRef]

237. Berman, A.; Klak, M.; Adamiok, A.; Kaczyński, Ł.; Tymicki, G.; Gomółka, M.; Kowalska, P.; Kosowska, K.; Cywoniuk, P.; Turowski, P.; et al. The Influence of the Flow of Detergent and Donor Characteristics on the Extracellular Matrix Composition After Human Pancreas Decellularization. Transplant. Proc. 2020, 52, 2043-2049. [CrossRef]

238. Klak, M.; Kosowska, K.; Majdanska, E.; Dobrzanski, T.; Berman, A.; Kaczynski, L.; Kowalska, P.; Gomolka, M.; Wszoła, M. Towards 3D-Bioprinting of Bionic Pancreas: Effect of Pressure on the Viability of Pancreatic Islets. In Proceedings of the 2019 American Transplant Congress, Hoboken, NJ, USA, 3 June 2019.

239. Guzowski, J.; Korczyk, P.M.; Jakiela, S.; Garstecki, P. Automated High-Throughput Generation of Droplets. Lab Chip 2011, 11, 3593-3595. [CrossRef] [PubMed]

240. Guzowski, J.; Garstecki, P. Droplet Clusters: Exploring the Phase Space of Soft Mesoscale Atoms. Phys. Rev. Lett. 2015, 114. [CrossRef] [PubMed] 